Pace University

DigitalCommons@Pace

\title{
Land Use for Energy Conservation and Sustainable Development: A New Path Toward Climate Change Mitigation
}

John R. Nolon

Elisabeth Haub School of Law at Pace University

Follow this and additional works at: https://digitalcommons.pace.edu/lawfaculty

Part of the Energy and Utilities Law Commons, Environmental Law Commons, and the Land Use Law Commons

\section{Recommended Citation}

John R. Nolon, Land Use for Energy Conservation and Sustainable Development: A New Path Toward Climate Change Mitigation, 27 J. Land Use \& Envtl. L. 295 (2012), http://digitalcommons.pace.edu/ lawfaculty/793/. 


\title{
LAND USE FOR ENERGY CONSERVATION AND SUSTAINABLE DEVELOPMENT: A NEW PATH TOWARD CLIMATE CHANGE MITIGATION
}

\author{
JOHN R. NOLON ${ }^{*}$
}

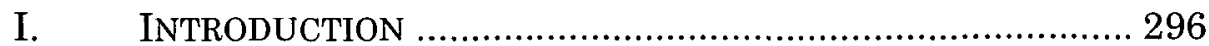

II. THE LAND USE-ENERGY CONSERVATION CONNECTION .... 297

A. Land Use, Energy Consumption, and Climate Change.

B. Human Settlement Patterns and Building

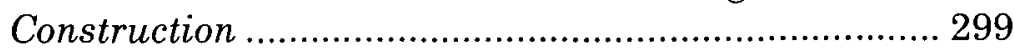

C. Demographic Trends and Their Impact..................... 300

D. Changing Land Use Law in a Changing Climate ...... 301

III. ENERGY CODE ADOPTION AND ENHANCEMENT .................. 302

A. Energy Codes: Coverage and Legal Authority............. 302

B. The International Energy Conservation Code.............. 304

C. ASHRAE Standard 90.1 .......................................... 305

D. Code Enforcement and the Building Approval

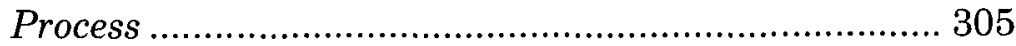

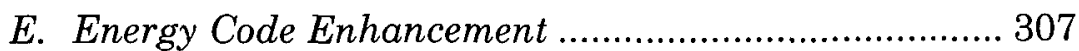

1. Legal Authority to Require or Incentivize

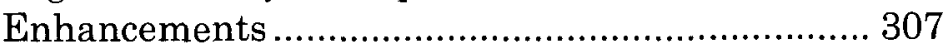

2. Energy Star Standards........................................ 309

3. ASHRAE Standard 189.1 ................................. 311

4. Core Performance ............................................... 312

5. Combined Heat and Power.................................. 312

6. Requiring Energy Efficient Appliances ................ 312

IV. LAND USE REGULATIONS AND ENERGY EFFICIENCY IN

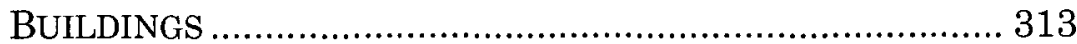

A. Land Use Objectives Include Energy Conservation .... 313

B. Passive Solar, Building Form, and Orientation .......... 316

C. Building Commissioning............................................. 317

D. Systems Approaches to Building Design .................... 317

E. Land Use Approval Protocols ...................................... 318

V. INTEGRATED NEIGHBORHOOD PLANNING........................ 318

A. Densities, Sustainability, and Energy Conservation at the Neighborhood Level......................................... 318

B. Transit Oriented Development ................................... 319

C. Transportation and Land Use Planning .................. 320

* John R. Nolon is James D. Hopkins Professor of Law at Pace Law School, Visiting Professor at the Yale School of Forestry and Environmental Studies, and Counsel to the Pace Land Use Law Center. He is indebted for the tireless efforts of his research assistant, Joseph Fornadel, and for the technical guidance of his colleagues at the Pace Energy and Climate Center. 
D. Local TOD Case Studies ............................................. 322

E. Transportation Efficient Development ........................ 325

F. LEED for Neighborhood Development ....................... 326

1. Overview of the LEED-ND Rating System........... 326

2. Municipal Use of LEED-ND to Guide Land

Development...................................................... 328

G. District Energy Systems ............................................ 330

VI. CONCLUSION: ENERGY CONSERVATION DISTRICTS ........... 334

\section{INTRODUCTION}

Land use tools and techniques have impressive potential to reduce energy consumption, improve the economy, and mitigate climate change. This article explores the little understood influence of local land use decision-making on energy conservation and sustainable development and how it can mitigate climate change if properly assisted by the federal and state governments. The construction and use of buildings combined with extensive vehicular travel throughout the nation's human settlements consume large amounts of energy, and much of that consumption is highly inefficient. By enforcing and enhancing energy codes, encouraging the use of combined heat and power and district energy systems, properly orienting and commissioning buildings, incorporating renewable energy resources, facilitating compact, mixed-use development, and promoting transit and other methods of reducing vehicle miles travelled ("VMT"), local land use law's potential to achieve energy conservation and sustainable development can be unlocked. These techniques can be organized at the neighborhood level and aggregated by adopting local Energy Conservation Zoning Districts in neighborhoods where significant energy conservation can be achieved. The article proposes federal and state policies, combining features of both the Coastal Zone Management Act and the Enterprise Zone initiative that can facilitate local land use initiatives that will shape human settlements and control the built environment as a new path toward energy efficiency and climate change mitigation. ${ }^{1}$

1. This article is one of four that examine how local land use law can be used as an effective strategy to mitigate climate change. See John R. Nolon, The Land Use Stabilization Wedge Strategy: Shifting Ground to Mitigate Climate Change, 34 WM. \& MARY ENVTL. L. \& POL'Y REV. 1 (2009) [hereinafter Land Use Stabilization Wedge]; John R. Nolon, Managing Climate Change through Biological Sequestration: Open Space Law Redux, 31 STAN. ENVTL. L.J. (forthcoming Spring 2012) (manuscript on file with author) (hereinafter Open Space Law Redux]; John R. Nolon, Regulatory Takings and Property Rights Confront Sea Level Rise: How Do They Roll?, 21 WIDENER L.J. (forthcoming 2012) (manuscript on file with author). 


\title{
II. THE LAND USE-ENERGY CONSERVATION CONNECTION
}

\author{
A. Land Use, Energy Consumption, \\ and Climate Change
}

According to the most conservative United States Bureau of Census estimates, our population will increase by over 100 million by mid-century. ${ }^{2}$ In order to accommodate this growth, as much as sixty-six percent of the development on the ground in 2050 will be built between now and then. ${ }^{3}$ The construction and operation of buildings as well as the VMT for daily work, errands, and pleasure will account for a large percentage of the energy needs by mid-century.

The Intergovernmental Panel on Climate Change (IPCC) released its "Fourth Assessment Report" on climate change in 2007. ${ }^{4}$ According to this document, global temperatures and sea levels have risen dramatically. ${ }^{5}$ In the IPCC's words, these changes are "very likely due to the observed increase in anthropogenic [greenhouse gas] (GHG) concentrations," as global GHG emissions have risen "70\% between 1970 and 2004." $\mathrm{CO}_{2}$ specifically composed $77 \%$ of total anthropogenic GHG emissions in 2004, resulting in 38 gigatonnes $(\mathrm{Gt})$ of $\mathrm{CO}_{2}$ being released into the atmosphere. ${ }^{7} \mathrm{As}$ of $2009, \mathrm{CO}_{2}$ represents $83 \%$ of the total GHG emissions in the Unit-

2. The Census Bureau released national population projections, based on four different immigration scenarios. National Population Projections, U.S. CENSUS BUREAU, http:/www.census.gov/population/www/projections/2009summarytables.html (last visited July 5, 2012). The "Low Net International Migration Series" predicted that the population would be $402,320,000$ by 2043 and would be $422,554,000$ by 2050. Summary Tables: Low Net International Migration Series, U.S. CENSUS BUREAU, http:/www.census.gov/ population/www/projections/2009InmsSumTabs.html (follow the "Excel" link under the heading " 1 . Projections of the Population and Components of Change for the United States: 2010 to 2050 ") (last visited July 5,2012 ). This is roughly a $1 / 3$ increase in the population by the year 2043 .

3. Reid Ewing et al., Urban Land Inst., Growing Cooler: The Evidence on URBAN DEVELOPMENT AND ClimATE CHANGE 8 (2007).

4. InTergovernmental Panel on Climate Change (IPCC), Climate Change 2007: SYNTHESIS REPORT (2007), available at http://www.ipcc.ch/pdf/assessment-report/ar4/syr/ ar4_syr.pdf [hereinafter IPCC SYNTHESIS REPORT]. See generally JOHN R. NOLON \& PATRICia E. Salkin, Climate Change and Sustainable Development LaW in a Nutshell 22 23 (2011) (indicating the sufficiency of the reports the IPCC report was based on by stating that "[o]ver 40 writing teams and 450 lead authors-selected as lead authors because of their expertise-contributed to the Fourth Assessment Report. The report contains over 18,000 citations to scientific reports, the majority of which were published in peer-reviewed journals. The lead authors were assisted by over 800 scientists and analysts who participated as contributing authors on specific topics. These authors contributed their time and were assisted by four Technical Support Units with paid staff.").

5. See IPCC SYNTHESIS REPORT, supra note 4, at 30.

6. Id. at 36,39 .

7. Id. at 36 . 
ed States. ${ }^{8}$ The IPCC's Special Report on Emissions Scenarios projects an increase of global GHG emissions by 25 to $90 \%\left(\mathrm{CO}_{2}\right.$-eq $)$ between 2000 and 2030. ${ }^{9}$ Consistent with such an increase, "[c]ontinued GHG emissions at or above current rates would cause further warming and induce many changes in the global climate system during the 21 st century that would very likely be larger than those observed during the 20th century." 10

In the United States, observable signs of climate change include increased air and water temperatures; degradation of fresh water fish habitat; diminished terrestrial biodiversity; increased bleaching and die-off of coral reefs; increased frequency and intensity of heavy downpours; a rise in sea level; reduced snow cover, glaciers, permafrost, and sea ice; reduced water supply in some regions; a longer ice-free period on lakes and rivers; a longer growing season; and increased water vapor in the atmosphere. ${ }^{11}$ These changes will affect human health, ${ }^{12}$ water supply, ${ }^{13}$ agriculture, ${ }^{14}$ coastal areas,,$^{15}$ and many other aspects of society and the natural environment. ${ }^{16}$ This report effectively introduces the broad range of issues that climate change raises, but it presupposes that climate change is happening. This has been carefully documented and is now widely accepted by a growing number of respected institutions and agencies. ${ }^{17}$

No matter how we grow, the energy consumed in construction, building operation, and travel will worsen climate change. ${ }^{18}$ This puts great pressure on policymakers, regulators, and the development industry to shape and control new development to minimize energy use and the resultant emissions caused by development. Under our legal system, the legal rules that dictate energy efficiency in new buildings and the frequency and intensity of travel within and between human settlements are often created and routinely enforced by local cities, villages, towns, and counties. ${ }^{19}$

8. U.S. ENVTL. Prot. AGENCY, INVENTORY of U.S. GREenhouse Gas EMISSIONS AND SINKS: 1990-2009, at ES-6 (2011) [hereinafter EPA GREENHOUSE GAS INVENTORY].

9. IPCC SYNTHESIS REPORT, supra note 4, at 44.

10. Id. at 45 .

11. U.S. Global Change Research Program, Global Climate Change impacts in THE UNITED STATES 9 (2009) [hereinafter GLoBal Climate Change IMPACTS IN THE U.S.]. The U.S. Global Change Research Program was charged with the responsibility of preparing this report by the Federal Advisory Committee Act. Id. at 7 .

12. Id. at 89.

13. Id. at 41 .

14. Id. at 71 .

15. Id. at 12 .

16. Id. at 99 .

17. See Open Space Law Redux, supra note 1 (manuscript at 5-9).

18. See infra text accompanying notes $21-23$.

19. See Land Use Stabilization Wedge, supra note 1, at 21-26; Open Space Law Redux, supra note 1 (manuscript at 11-19). 


\section{B. Human Settlement Patterns and Building Construction}

Residential and commercial buildings use an extraordinary amount of electricity and energy. In 2008, U.S. residential and commercial buildings used 29.29 quadrillion BTUs, which was $73.2 \%$ of all electricity produced in the United States. ${ }^{20}$ The Department of Energy projects that by 2035 , residential and commercial buildings will use $76.5 \%$ of the total electricity in the United States. ${ }^{21}$ Furthermore, "[r]oughly $41 \%$ of total U.S. energy consumption in 2010 was used in [residential and commercial] buildings . ..."22 Inherent to the nation's energy system are significant inefficiencies. Two-thirds of the energy used to produce electricity is vented as heat that escapes into the atmosphere during generation, ${ }^{23}$ and up to $15-20 \%$ of the net energy produced at these plants is lost in transmission: so-called line losses. ${ }^{24}$

Due to the large amount of electricity that residential and commercial buildings require, these buildings are responsible for a significant amount of GHG emissions. In 2009, residential and commercial buildings accounted for thirty-five percent of $\mathrm{CO}_{2} \mathrm{e}$ emissions, totaling $2.34 \mathrm{Gt} \mathrm{CO}_{2 \mathrm{e}}{ }^{25}$ Improvements in the generation of electricity and its transmission to these buildings, and in building construction can significantly lower energy waste and use and greatly lower GHG emissions in the United States.

One of the main drivers of GHG emissions and thus climate change is transportation. Nationally, the EPA found that "[t]ransportation activities . . . accounted for [thirty-three] percent of $\mathrm{CO}_{2}$ emissions from fossil fuel combustion in $2009 \ldots$. Nearly [sixty-five] percent of [these] emissions resulted from gasoline consumption for personal vehicle use." ${ }^{26}$ For example, passenger cars alone emitted 0.6274 $\mathrm{Gt} \mathrm{CO}_{2} \mathrm{e}$ in 2009. ${ }^{27}$ Although between 2008

20. U.S. Residential and Commercial Buildings Total Primary Energy Consumption, U.S. DEP'T OF ENERGY, http://buildingsdatabook.eren.doe.gov/TableView.aspx?table=1.1.1 (last updated Mar. 2012).

21. Id.

22. How Much Energy is Used in Buildings in the United States?, U.S. ENERGY INFo. ADMIN., http://www.eia.gov/tools/faqs/faq.cfm?id=86\&t=1 (last reviewed Nov. 30, 2011).

23. E-mail from Thomas Bourgeois, Deputy Dir., Pace Energy \& Climate Ctr., to author (June 30, 2011, 21:55 EST) (on file with author).

24. E-mail from Thomas Bourgeois, Deputy Dir., Pace Energy \& Climate Ctr., to author (June 30, 2011, 17:22 EST) (on file with author).

25. EPA GREENHOUSE GAS INVENTORY, supra note 8 , at $2 \cdot 20$. This enormous quantity of emissions is understandable, as eighty-three percent of energy consumed in the United States relied on carbon-intensive fossil fuels. See Renewable Energy Consumption and Electricity Preliminary Statistics 2009, U.S. ENERGY INFO. ADMIN., http://www.eia.doe.gov/cneaf/ alternate/page/renew_energy_consump/rea_prereport.html (last visited July 5, 2012).

26. EPA GREENHOUSE GAS INVENTORY, supra note 8, at ES-8.

27. Id. at $2 \cdot 22$. 
and 2009 there was a decrease in national $\mathrm{CO}_{2}$ emissions, this decrease was temporary and is not indicative of a permanent shift away from carbon emission-trends related to vehicle travel. ${ }^{28}$

A useful measure of transportation levels is a count of the total VMT by Americans. Unfortunately, "[v]ehicle miles traveled (VMT) in the [United States] has grown three times faster than population [since 1980], and almost twice as fast as vehicle registrations ... . Only $13 \%$ was explained by population growth," out of a total $36 \%$ increase in VMT. ${ }^{29}$ This increase appears to be largely driven by personal auto use, as "vehicle miles traveled by lightduty motor vehicles (passenger cars and light-duty trucks) increased [thirty-nine] percent from 1990 to $2009 . " 30$ "[VMT] may exceed seven trillion . . . miles by 2055," which is much higher than the three trillion traveled in $2006 .{ }^{31}$

One way to combat this projected rise in VMT is to promote urban settlement, as urban residents generally drive less than suburban or rural residents. ${ }^{32}$ Residents of compact urban neighborhoods drive between twenty to forty percent less than suburban residents. ${ }^{33}$ Directly related to this reduction in VMT, research has shown that per capita energy consumption and GHG emissions are two to two and a half times higher in areas of low density development, when compared to high density areas. ${ }^{34}$

\section{Demographic Trends and Their Impact}

It is estimated that, by 2050 , eighty-nine million new and replacement residential units and " 190 billion additional square feet

28. Id. at 2-1 ("The following factors were primary contributors to this decrease [from 2008 to 2009]: (1) a decrease in economic output resulting in a decrease in energy consumption across all sectors; and (2) a decrease in the carbon intensity of fuels used to generate electricity due to fuel switching as the price of coal increased, and the price of natural gas decreased significantly.").

29. Keith Bartholomew \& Reid Ewing, Address at the 87th Transportation Research Board Annual Meeting: Land Use-Transportation Scenario Planning in an Era of Global Climate Change 4 (Nov. 5, 2007).

30. EPA GREENHOUSE GAS INVENTORY, supra note 8, at 2-21.

31. Am. Ass'n of State Highway \& Transp. Officials, Future Needs of the U.S. SURFACE TRANSPORTATION SYSTEM 18 (Feb. 2007)

32. See EWING ET AL., supra note 3, at 2. In fact, given location efficient transit planning, "a household can reduce its GHG emissions by as much as [seventy-eight] percent." Peter haAs et al., Ctr. For Neighborhood Tech., Transit Oriented Development and The Potential for VMT-RELATEd Greenhouse Gas Emissions Growth ReduCTION 33 (2010), available at http://www.cnt.org/repository/TOD-Potential-GHG-EmissionsGrowth.FINAL.pdf.

33. See id. at 9 .

34. Patrick M. Condon et al., Lincoln Inst. of Land Policy, URBan Planning Tools for Climate Change Mitigation 8 (2009). 
of nonresidential space" will be created. ${ }^{35}$ Where these buildings are located and how they are built will dictate how much this new construction will increase energy consumption and GHG emissions; this depends on the preferences of the new households that will be added to the population. The demographics of the American population will change in the future, shifting towards more childless and single-person households. By 2030, the percentage of households with children will decrease to twenty-seven percent, while households without children will rise to seventy-three percent. ${ }^{36}$ Single individuals, living alone, will account for thirty-four percent of all households. ${ }^{37}$

Because these new households will seek housing and jobs suited to their needs, land use regulation must evolve to promote development in line with these changing market demands. ${ }^{38}$ Research has "previously shown that there is enough large lot singlefamily development on the ground to meet the . . . demand [for such housing through] 2025." 39 As of 2010, there was more demand than supply for both attached residential units and small lot units. ${ }^{40}$ In contrast, there was a higher supply of large lot units than demand. ${ }^{41}$ The demand for smaller housing units will grow. "[B] etween 2010 and 2050, more single-person households will be added than households with children. Moreover, roughly twothirds to three-quarters of the net gain in households between 2010 and 2050 will be among households without children." 42 A 2011 National Association of Realtors survey found that if people could choose where to live, forty-seven percent would choose to live in a city or suburban mixed-use community. ${ }^{43}$

\section{Changing Land Use Law in a Changing Climate}

There are numerous land use strategies available to state and local governments to achieve significant energy conservation as we

35. Memorandum from Reid Ewing, Arthur C. Nelson \& Keith Bartholomew, Response to Special Report 298 Driving and the Built Environment: The Effects of Compact Development on Motorized Travel, Energy Use, and CO2 Emissions 3 (Sept. 16, 2009), available at http://www.smartgrowthamerica.org/documents/ResponsetoTRBSpecialReport. pdf [hereinafter Response to 298].

36. Arthur C. Nelson, Presidential Professor \& Dir., Metro. Reserch Ctr., Univ. of Utah, Address at the 2011 Journalists Forum at Lincoln Inst. of Land Policy: Land on the Built Environment: The Next City (Apr. 15-16, 2011), available at https:// www.lincolninst.edu/docs/771/1282_Nelson - Final.pptx.

37. Id.

38. Id.

39. Response to 298 , supra note 35 , at 4 .

40. Nelson, supra note 36 .

41. Id.

42. Response to 298 , supra note 35 , at 4 .

43. Nelson, supra note 36 . 
build and substantially renovate individual buildings and plan neighborhood development to accommodate the nation's growing population. In the aggregate, these strategies can create urban settlements that not only consume less energy but create livable and exciting places for future generations to inhabit.

Part three of this article discusses enforcing and enhancing adopted energy conservation codes and explores a variety of ways that local governments can supplement energy conservation standards in individual buildings. Part four describes the connection between energy conservation and the land use regulatory process and discusses several techniques that can lower consumption and increase efficiency. In Part five, we turn to neighborhood-scale planning and demonstrate how transit oriented development, sustainable neighborhood planning, and district energy systems can be fostered by local land use plans and regulations. These strategies are capable of reducing fossil fuel consumption and tailpipe emissions by facilitating walking and biking, thus lowering the number of vehicle trips and VMT. Part six concludes by arguing that the aggregation of these strategies through the adoption of Energy Conservation Zones can shape human settlements to achieve sustainable development patterns that require less energy to build and occupy, thus contributing to America's quest for energy independence, affordability, and climate change mitigation.

\section{ENERGY CODE ADOPTION AND ENHANCEMENT}

\section{A. Energy Codes: Coverage and Legal Authority}

In the United States' legal system, the principal method of achieving energy efficiency in new building construction and the substantial renovation of buildings is through the energy conservation code. ${ }^{44}$ The basic energy code, applicable in most states, contains minimum standards for the design, construction, and installation of the building shell or "envelope," mechanical systems, and lighting. ${ }^{45}$ In the evolution of building codes in the United States,

44. See thomas W. Fleming, Freshwater Dev. Co., Energy Codes - Origins AND CURRENT PRACTICES: A PRIMER (2009), available at http://www.freshwaterfl.com/ EnergyCodesPrimer.pdf; Jessica A. Bacher \& Jennie C. Nolon, Energy Codes, Green Building Initiatives, and Beyond, 38 REAL EST. L.J. 231 (2009). Energy conservation codes are either adopted by state governments-which typically require local enforcement and may allow localities to adopt stricter standards—or by local governments directly. See BLDG. CODES Assistance PROJECT, http://www.bcap-energy.org/who-we-are/history-and-mission/ (last visited July 5, 2012); see also Building Energy Codes Program, U.S. DEP'T OF ENERGY, http://www.energycodes.gov (last updated Apr. 30, 2012).

45. Land Use Stabilization Wedge, supra note 1, at 38 (citing INT'L CODE COUNCIL, INTERNATIONAL ENERGY CONSERVATION CODE, at iii (2009)). 
the energy code is a relative newcomer, and a much-welcomed addition to the family of codes that has historically regulated building construction, plumbing, fire prevention, and electrical systems. ${ }^{46}$ The explicit goal of the energy code is to reduce the energy consumed by new and substantially renovated buildings to which building construction codes apply. ${ }^{47}$

Every few years, energy codes are strengthened to add newlyevolved technologies and to accomplish ever-increasing degrees of energy conservation. Some states and local governments, aware that building technology exists that can make new buildings extraordinarily efficient, add new provisions to their codes more quickly than others; thus, they enhance their codes with new provisions that achieve deeper efficiencies. ${ }^{48}$ Some local governments supplement energy codes with land use regulations that govern matters beyond the scope of building codes. Energy codes, for example, do not cover building orientation, layout, or landscaping on sites, which can be used to reduce energy consumption in new buildings. ${ }^{49}$ These efficiencies can be accomplished through site plan regulations imposed and enforced by local land use boards. As a result, for local energy codes to achieve the maximum energy and climate efficiency, they must be enhanced through stricter provisions or supplemented by local land use regulations and project approval practices that can reach beyond the coverage of the basic energy code.

The power of local governments to amend energy codes varies from state to state. A few states have not adopted a statewide energy code, thereby leaving it to their local governments to decide whether to do so. ${ }^{50}$ Some states have adopted a state energy code and have preempted local governments from adopting and enforcing stricter standards. ${ }^{51}$ Other states have adopted a basic energy code, along with a separate set of stricter stand-

46. See, e.g., Building and Construction Codes, N.Y. STATE LIBRARY, http://www.nysl.nysed.gov/reference/building/\#webster (last updated June 9, 2009).

47. See generally Craig DiLouie, States Incorporate Energy Standard in Lighting Design Requirements, ELECTRICAL CONSTRUCTION \& MaINTENANCE Mag., Jan. 2005, available at http://ecmweb.com/mag/electric_states_incorporate_energy/ (explaining the motivation behind the new code and its widespread adoption across the United States).

48. See Land Use Stabilization Wedge, supra note 1, at 39 (citing CiTY of ARCATA, Cal., Community Greenhouse Gas Reduction Plan (2006), available at http://www. cityofarcata.org/sites/default/files/files/document_center/EnvironmentalServices/Energy/ Greenhouse Gas Reduction Plan.pdf).

49. Id. (citing INT'L CODE COUnCIL, InTERnational ENERgy Conservation COdE (2006)).

50. Id. (citing Steven Bodzin, State Energy Codes: An Uphill Battle, Home ENERGY, Mar.-Apr. 1997, available at http://www.homeenergy.org/show/article/magazine/102/id/1288.

51. Id. (citing BCAP, Home Rule and Energy Codes: An Introductory Outline, ONLINE CODE ENV'T \& ADVOCACY NETWORK (Mar. 2009), http://energycodesocean.org/sites/default/ files/resources/Home_Rule_outline_FINAL.pdf). 
ards, which localities are permitted to adopt in their discretion..$^{52} \mathrm{~A}$ final group of states has adopted a statewide mandatory code and allow local governments to enact stricter standards as a matter of local perogative..$^{53}$

\section{B. The International Energy Conservation Code}

Most states and municipalities that adopt energy codes use the International Energy Conservation Code (IECC) promulgated by the International Codes Council (ICC). ${ }^{54}$ Over eighty percent of the states in the United States have adopted the IECC as their standard. ${ }^{55}$ The ICC was established in 1994 as a non-profit organization with the purpose of developing a single set of model construction codes, including building construction, plumbing, electrical, and energy conservation, among other topics.56 The ICC was founded by Building Officials and Code Administrators International, Inc., the International Conference of Building Officials, and Southern Building Code Congress International, Inc. ${ }^{57}$ These predecessor organizations developed three separate sets of model codes that were adopted or adapted by many of the states within their regions. ${ }^{58}$

By forming the ICC, these three professional organizations paved the way for the development of one national energy conservation code. The resulting IECC is divided into two primary parts. One regulates the construction of smaller residential buildings (one- and two-family homes and multifamily buildings three stories in height or less); the other regulates all other buildings, generally denominated "commercial" buildings, including larger residential buildings. ${ }^{59}$

52. Id. at $39-40$.

53. Id. at 39 .

54. See Bacher \& Nolon, supra note 44, at 234 (citing see Code Status: Commercial, ONLINE CODE ENV'T \& ADVOCACY NETWORK, http://www.energycodesocean.org/code-statuscommercial; see also Code Status: Residential, ONLINE CODE ENV'T \& ADVOCACY NETWORK, http://www.energycodesocean.org/code-status-residential).

55. International Codes - Adoption by State, INT"L CODE CounCIL, http://www.iccsafe. org/gr/Documents/stateadoptions.pdf (last updated Apr. 26, 2012) (forty-two out of the fifty states have adopted the IECC).

56. About ICC, INT'L CODE COUNCIL, http://www.iccsafe.org/AboutICC/Pages/default .aspx (last visited July 5, 2012).

57. Id.

58. $I d$.

59. Bacher \& Nolon, supra note 44, at 234; see also Land Use Stabilization Wedge, supra note 1, at 38 (citing INT'L CODE COUNCIL, INT'L ENERGY CONSERVATION CODE $§ 202$, ch. 6 (2006)); What is the International Energy Conservation Code?, RESPONSIBLE ENERGY CODES ALLIANCE, http://www.reca-codes.org/about-iecc.php (last visited July 5, 2012). 


\section{ASHRAE Standard 90.1}

Most commercial buildings built today are designed to conform to "Standard 90.1, promulgated by the American Society of Heating, Refrigerating, and Air Conditioning Engineers (ASHRAE)," which is incorporated by reference into the IECC. 60 ASHRAE, an international member organization founded in $1894,{ }^{61}$ issued its first set of energy standards for commercial buildings, Standard 90, in 1975.62 Standard 90.1 is the most frequently used benchmark for commercial building energy construction, and it is constantly updated to keep pace with changing technology. ${ }^{63}$ Today, this ASHRAE standard addresses the building envelope; heating, ventilation, and air-conditioning (HVAC) systems; water heating; power; lighting; other equipment; and boiler efficiency improvements. ${ }^{64}$

\section{Code Enforcement and the Building Approval Process}

Compliance with building, plumbing, electrical, fire, and energy codes is a prerequisite for obtaining a building permit and a certificate of occupancy (CO) from local governmental agencies empowered to regulate development. ${ }^{65}$ The $\mathrm{CO}$ is the end point in the local land use regulatory process. It signifies compliance with all land use regulations, with all conditions imposed on a project's approval, and with all applicable building codes. Architects and engineers are engaged to draw plans for new buildings. Once a development proposal is determined to comply with zoning and site plan standards, these professionals draw plans for the construction of the buildings themselves, and these plans must incorporate and comply with every standard contained in applicable codes. ${ }^{66}$ If they

60. Land Use Stabilization Wedge, supra note 1, at 38 (citing Thomas E. Glavinich, Energy Codes, Electrical ConTRACTOR MAG. (Sept. 2005), http://www.ecmag.com/ index.cfm?fa=article\&articleID=6430); see also 2009 Commercial Energy Efficiency, RESPONSIBLE ENERGY CODES ALLIANCE, http://www.reca-codes.org/2009-commercial.php (last visited July 5,2012 ).

61. About ASHRAE, ASHRAE.oRG, http://www.ashrae.org/about-ashrae/ (last visited July 5, 2012).

62. ASHRAE, ASHRAE STANDARD: ENERGY STANDARD FOR BUILDINGS EXCEPT LOW-RISE RESIDENTIAL BUILDINGS 4 (2010), available at http://openpub.realread.com/ rrserver/browser?title=/ASHRAE_1/ashrae_90_1_2010_IP_1024.

63. See Bacher \& Nolon, supra note 44 , at $234-35$.

64. ASHRAE, supra note 62 , at 4.

65. Land Use Stabilization Wedge, supra note 1, at 37-38 (citing INT'L CODE CoUNCIL, INTERNATIONAL ENERGY CONSERVATION CODE $§ 105.1$ (2003) (commentary)).

66. See Brian W. Blaesser \& Thomas P. Cody, Entitlement Processes in Redevelop. ment, in Redevelopment: Planning, LaW, AND PRojeCt IMPLEMENTATION 213, 221 (Brian W. Blaesser \& Thomas P. Cody eds., 2008). 
do not, the local code enforcement department will reject the drawings and refuse to issue the developer a building permit. ${ }^{67}$

Once a building permit is issued, construction begins and local code enforcement personnel monitor and inspect the building to ensure that its construction complies with the permit. ${ }^{68}$ If inspections indicate that code standards are being violated, a stop work order can be issued to the developer and, if work is not halted and the violations cured, the local government can go to court for an injunction and for imposition of civil, and sometimes criminal, penalties. Upon completion, the building is certified as code compliant and a CO is issued. It is only then that the building's owner is allowed to occupy the premises. If the building is a single-family home, the $\mathrm{CO}$ allows the homeowner to enter and begin residence. If it is a large commercial building, its owner can occupy or lease the premises following the issuance of the CO.

Energy code enforcement at the local level consists principally of having one or more code inspectors who are trained in the code, know its standards, ensure that they are met by the drawings and during construction, and then sign off on the $\mathrm{CO}$, which certifies that the building has met all local standards, including zoning, site plan, building, plumbing, fire, electricity, and energy requirements. ${ }^{69}$ Because local governments are often fiscally constrained, and because energy code enforcement is regarded in some local building departments as less critical to life and safety than compliance with building, fire, and other codes, many localities and states have less than adequate track records in enforcing energy code standards. ${ }^{70}$

States typically require training of local code inspectors and make training programs available to be sure that local inspectors are familiar with the energy code provisions. ${ }^{71}$ States, too, are fiscally challenged and fail in some instances to provide adequate training accessible to current and newly employed code inspectors. ${ }^{72}$ In the constellation of energy conservation and carbon emission reduction strategies, one of the most important actions is for state and local governments to properly enforce the energy code. ${ }^{73}$ Federal initiatives that make funding or other incentives available for energy code enforcement help with this essential function of the

67. See id. at $219-21$.

68. U.S. DEP'T OF ENERGY, BUILDING ENERGy Codes 101: AN INTRODUCTION 17-18 (2010), available at http://bcap-ocean.org/sites/default/files/resources/20100301_std901_ codes_101.pdf (describing the permitting and enforcement process).

69. See id.

70. Id. at 18 .

71. See Bacher \& Nolon, supra note 44, at 233.

72. See U.S. DEP'T OF ENERGY, supra note 68 , at 3.

73. Id. at 17 . 
legal system. ${ }^{74}$ Strengthening energy code compliance through training of local code enforcers and through better enforcement and monitoring procedures are relatively inexpensive strategies that will pay off significantly in energy conservation and the reduction of future carbon emissions.

\section{E. Energy Code Enhancement}

\section{Legal Authority to Require or Incentivize Enhancements}

States that either allow local governments to enhance statewide codes or that adopt their own statewide enhancement provisions understand that buildings can be made more energy efficient than by what is achieved through the provisions of the base energy code. ${ }^{75}$ Adopting stricter standards, of course, increases the capital costs of new and substantially renovated buildings. There is natural tension between accomplishing more efficiency and increasing costs beyond the point of reason. When codes require capital improvements that do not offer short-term paybacks, they may simply discourage development or generate lawsuits.

This financial and political reality divides the attention of policymakers between regulation and the provision of incentives. The base energy code achieves important, but limited, conservation because the additional costs its provisions impose on builders are relatively modest. Certain stricter code provisions involve, in the opinion of their advocates, higher costs, but costs that are recouped within a reasonable period by the savings achieved. Achieving even greater efficiencies requires that governmental agencies or utility companies provide incentives to induce owners to expend the greater capital outlays involved. The recent history of energy code enhancement and energy efficiency incentives involves a range of reactions to the tensions between capital costs, energy savings, and the need for incentives versus regulations.

In Marin County, California, where state energy conservation code provisions are enforced, the County adopted a straightforward method of enhancing energy performance of new single-family homes. ${ }^{76}$ Homes under 4000 square feet are required to exceed the energy conservation performance required by the state code by fif-

74. One example being the International Code Council's collaboration with the Department of Energy to get federal funding to provide free copies of the IECC 2009. Free 2009 IECC Download Instructions, INT'L CODE COUNCIL, http://www.iccsafe.org/store/pages/ doeregistration.aspx? $\mathrm{r}=$ FreeIECC (last visited July 5, 2012). While the offer has expired, this program illustrates that collaboration between the federal government and private organizations can be used to improve energy code enforcement.

75. Land Use Stabilization Wedge, supra note 1, at 37-39.

76. See CNTY. OF MARIN, CAL., ORDINANCE $\S 19.04 .100$ (2011). 
teen percent. ${ }^{77}$ If the home is over 4000 but fewer than 5500 square feet, it must exceed the state code in efficiency by twenty percent. ${ }^{78}$ For homes between 5500 and 6500 square feet the requirement is thirty percent, and large homes, over 7000 square feet must be "net zero energy" users. ${ }^{79}$ Similar standards with different thresholds and energy reduction requirements apply to multi-family and commercial buildings. ${ }^{80}$ This approach to base energy code enhancement discourages the construction of larger, more energy consumptive buildings, or forces the purchasers of large, expensive homes to invest more in energy efficiency.

The process of energy code enhancement at the state level is illustrated in the Massachusetts Green Communities Act of 2008, which includes a supplemental set of standards that localities may adopt. ${ }^{81}$ While the state's energy code is the same as those adopted in most states, a state-adopted "stretch code" gives local governments the option of adopting a package of more restrictive provisions if the local political and economic climate permit them to do so. The stretch code enhancements for smaller residential buildings are based on the Home Energy Rating System (HERS) standards and the Residential Energy Services Network (RESNET) rating approach. ${ }^{82}$ For commercial buildings, enhancements are based on the latest version of the IECC, which is more restrictive than the version adopted by Massachusetts as its base code and the New Buildings Institute's Core Performance Guide for commercial buildings, discussed further below. ${ }^{83}$ Third party standards such as Energy Star for Homes or the Core Performance Guide are created for the discrete purpose of enhancing the energy performance of buildings over and above that achieved by the base code. By adopting such third party standards as state or local law, an additional level of efficiency is achieved that is within the realm of economic reasonableness.

The State of New York allows local governments to adopt standards more restrictive than the New York State Energy Conservation Construction Code. The Town of Greenburgh amended its local code to require that all new homes (small residential buildings) constructed in the town achieve a certain HERS index value. ${ }^{84}$

77. Id. $\$ 19.04 .100(\mathrm{E})$

78. Id.

79. Id

80. $I d$.

81. S. 2768, 2008 Leg., 2d Ann. Sess. (Mass. 2008).

82. Stretch Energy Code, 780 MASS. CODE REGS. CH. 120.AA (2011).

83. Id.

84. GREENBURGH, N.Y., TOWN CODE $§ 100-20$ (2011), available at http://www. ecode 360 . com/?custId $=$ GR0237. 


\section{Energy Star Standards}

The Greenburgh, New York example above illustrates how the Energy Star program can be used to enhance the requirements of the base energy conservation code. ${ }^{85}$ The Energy Star rating system is a joint venture of the Environmental Protection Agency (EPA) and the U.S. Department of Energy (DOE). ${ }^{86}$ Initially developed in 1992 as a program for labeling energy efficient computers and monitors, Energy Star has expanded, now covering a full range of appliances, heating and cooling systems, and even newly constructed residential and commercial buildings. ${ }^{87} \mathrm{~A}$ number of municipalities have incorporated Energy Star construction and appliance requirements into their codes, requiring thermal envelope efficiency, electrical savings, superior ventilation, and equipment efficiency requirements. ${ }^{88}$

Energy Star provides several methods of making buildings more energy efficient than most state energy code requirements. For homes, "[t]hese methods include more effective insulation, higher performance windows, more efficient heating and cooling equipment, tighter building envelopes to reduce air infiltration, and use of various energy efficiency products. The Home Energy Rating System (HERS) Index is used as the reference tool for ENERGY STAR-labeled residential buildings." ${ }^{9}$ The HERS index uses a scale ranging from zero to 150 , with zero being a building that uses no net energy. ${ }^{90}$ The standard building constructed today in the United States typically ranks around 100 on the Index.91 "To receive an Energy Star label, a home must achieve a minimum

\section{Id.}

86. Bacher \& Nolon, supra note 44, at 236; History of ENERGY STAR, ENERGY STAR, http://www.energystar.gov/index.cfm?c=about.ab_history (last visited July 5, 2012).

87. Bacher \& Nolon, supra note 44 , at 236; History of ENERGY STAR, ENERGY STAR, http://www.energystar.gov/index.cfm?c=about.ab_history (last visited July 5, 2012).

88. See, e.g., Blooming Grove, N.Y., Town Code $\S 235-14.1(\mathrm{~A})(3)$ (2011); Red Hook, N.Y., Town CODE $\S 74-20$ (2011); Exec. Order No. 123 from John W. Hickenlooper, Mayor, City of Denver (Oct. 24, 2007), available at http:/www.greenprintdenver.org/docs/ CCDX0123.pdf; ARlington DeP'T of EnvTl. Servs., Policy For INTEgrated FacilITY SUSTAINABILITY (2008), available at http:/freshaireva.us/wp-content/uploads/2012/01/ file699501.pdf; Bacher \& Nolon, supra note 44, at 236-237. Seattle also offers assistance to those who are looking to implement Green technology in their buildings. Seattle Climate Action Now, SEATTLE DEP'T OF PlannING \& Dev., http:/www.seattle.gov/dpd/ seattleclimateactionnow/ (last visited July 5, 2012) "Rather than mandating compliance, Seattle promotes use of these standards by providing homeowners with information and links to each of these programs on its Climate Action Now website - a central clearinghouse for information and activities related to climate change mitigation." Bacher \& Nolon, supra note 44 , at 237.

89. Bacher \& Nolon, supra note 44, at 236; see alsoWhat is a Home Energy Rating?, RESIDENTIAL ENERGY SERVS. NETWORK ("RESNET"), http://www.resnet.us/home-energyratings (last visited July 5, 2012).

90. Bacher \& Nolon, supra note 44 , at 236.

91. Id. 
HERS rating that varies by climate zone, with 80 required in some zones and 85 required in others." 92

Like many other third party standards and rating systems, "[Energy Star] guidelines for residential buildings may be adopted at the local level either as mandatory standards for new or renovated buildings" or as standards to be achieved through the provision of incentives. ${ }^{93}$ The Town of Blooming Grove, New York, uses a density bonus technique to encourage developers of homes to adopt Energy Star, rather than requiring compliance like the Greenburgh approach. ${ }^{94}$ The Town of Blooming Grove awards a ten percent increase in the number of homes that can be constructed under local zoning in exchange for making them all Energy Star compliant..$^{95}$ This is an illustration of using a municipality's delegated zoning authority to supplement energy code requirements.

A similar approach is followed by Seattle, Washington, which promotes green residential development through the use of Energy Star, among other third party standards.

Rather than mandating compliance, Seattle promotes use of these [enhanced] standards by providing homeowners with information and links to each of these programs on its Climate Action Now website-a central clearinghouse for information and activities related to climate change mitigation. The [c]ity also promotes [Energy Star through] its City Green Building Program, [under] which the Department of Planning and Development ... [assists] homeowners and builders [interested in using] green building technology for construction and remodeling projects. ${ }^{96}$

To set "an example for the private sector, Denver, [Colorado] requires Energy Star compliance for [buildings]" that are subsidized by the city. "Under Executive Order 123, city-funded new buildings and major renovations must be built in compliance with [Energy Star]."97 In Arlington, Virginia, "county buildings must be built and designed to meet [Energy Star] performance [stand-

92. Id.

93. Bacher \& Nolon, supra note 44 , at 236-37.

94. See Blooming Grove, N.Y., Town Code § 235-14.1(A)(3) (2011).

95. Id.

96. Bacher \& Nolon, supra note 44, at 237; See also Making Green Building Standard Practice, SEATTLE OFFICE of SustaINABILITY \& ENv'T, http://www.seattle.gov/dpd/ greenbuilding/ (last visited July 5, 2012); Seattle Climate Action Now, supra note 88.

97. Bacher \& Nolon, supra note 44, at 237; Exec. Order No. 123 from John W. Hickenlooper, Mayor, City of Denver (Oct. 24, 2007), available at http://www. greenprintdenver.org/docs/CCDXO123.pdf. 
ards]."98 The Arlington Initiative to Reduce Emissions recommends that small businesses adopt Energy Star standards to reduce energy use and emissions. ${ }^{99}$ To move them along, the county offers several types of free energy audits. ${ }^{100}$

\section{ASHRAE Standard 189.1}

ASHRAE, in conjunction with the United States Green Building Council (USGBC) and the Illuminating Engineering Society of North America (IESNA), developed Standard [189.1] . . . for the design and construction of highperformance green buildings. ${ }^{101}$ The intent behind its creation is for both public and private entities to use Standard [189.1] as a performance baseline. ${ }^{102}$ The Standard, which does not apply to low-rise residential buildings, is designed to achieve $30 \%$ greater energy efficiency than ASHRAE 90.1-2007. . . .103

Standard 189.1 goes beyond energy conservation. It includes aspects of site and building development such as site sustainability, water use efficiency, impact on the atmosphere, materials and resources, indoor environmental quality and construction and operation, as well as energy efficiency. ${ }^{104}$ Among the energy conservation enhancement features of Standard 189.1 are standards for appliances and lighting, and a requirement that on-site renewable energy systems provide at least one percent of the electricity needed. ${ }^{105}$ By implementing on-site generation, and requiring remote or automatic measuring devices for energy sources and key systems, Standard 189.1 can achieve its goal of thirty percent less energy use than buildings that comply with Standard 90.1.

98. Bacher \& Nolon, supra note 44 , at 237.

99. Id.; see also AIRE: Arlington Initiative to Reduce Emissions, ARLINGTON CNTY. Gov'T, http://freshaireva.us (last visited July 5, 2012).

100. Bacher \& Nolon, supra note 44 , at 237.

101. Id. at 236; See also ASHRAE \& U.S. GREen Bldg. Council, STANDARd For the DESIGN OF HIGH-PERFORMANCE GREEN BUILdings: EXCEPT LOW-RISE RESIDENTIAL BUILDINGS 2 (2011), available at http://openpub.realread.com/rrserver/browser?title=/ASHRAE_ 1/ashrae_189.1_113009M [hereinafter STANDARD FOR HIGH-PERFORMANCE GREEN BUILDINGS].

102. Bacher \& Nolon, supra note 44 , at 236; STANDARD FOR HIGH-PERFORMANCE GREEN BUILDINGS, supra note 101, at 2-3.

103. Bacher \& Nolon, supra note 44 , at 236.

104. STANDARD FOR HIGH-PERFORMANCE GREEN BUILDINGS, supra note 101, at 14-37.

105. Id. at $16,27$. 


\section{Core Performance}

The New Buildings Institute (NBI) is a non-profit organization whose primary goal is to improve energy efficiency in buildings. ${ }^{106}$ It has established a set of energy code enhancements that is available to state and local governments as a mechanism for enhancing their codes. Its Core Performance program is a prescriptive approach that can yield almost thirty percent energy savings above the IECC for commercial buildings smaller than 100,000 square feet. ${ }^{107}$ Core Performance is incorporated by reference in the State of Massachusetts's supplemental code that is available for local governments to adopt. ${ }^{108}$

\section{Combined Heat and Power}

Local land use laws such as zoning, subdivision, and site plan regulations can achieve extraordinary energy efficiency by permitting and encouraging the use of combined heat and power (CHP) systems in individual buildings and interconnected energy systems in certain mixed use districts. By employing CHP, a mechanical system that can be used to produce electricity, heat or both, in higher density, mixed use neighborhoods, the potential for energy efficiency, and therefore energy conservation and climate change mitigation, is exponentially greater than if used on an individual parcel of land.

\section{Requiring Energy Efficient Appliances}

Appliances include refrigerators, freezers, computers, televisions, and clothes dryers in residences, and a host of larger appliances and equipment in commercial buildings, including printers, faxes, and other office equipment. In commercial and residential buildings, the use of appliances and equipment account for a significant percentage of electricity use. ${ }^{109}$ In some places, equipment and appliances account for up to half of all energy used in both types of buildings. For this reason, some local governments have attempted to require developers to install energy efficient appliances and equipment in their buildings.

106. About Us, NEw BLDGS. INST., http://www.newbuildings.org/about-us (last visited July 5,2012$)$.

107. See Core Performance, ADvANCED BLDGS., http://www.advancedbuildings.net/coreperformance (last visited July 5, 2012).

108. See 780 MASS. CODE REGS. CH. 120.AA (2011).

109. See About ENERGY STAR, ENERGY STAR, http://www.energystar.gov/index.cfm? $c=$ about.ab_index (last visited July 5, 2012). 
In Air Conditioning, Heating \& Refrigeration Institute $v$. City of Albuquerque, a federal district court issued a preliminary injunction barring enforcement of certain provisions of the City of Albuquerque's green building code pending the outcome of a lawsuit, brought by appliance and equipment trade organizations, contractors, and distributors, on the ground that those code provisions were preempted by federal law. ${ }^{110}$ The city's green building code called for a thirty percent increase in energy efficiency for new commercial and residential buildings as well as for those undergoing substantial renovations. ${ }^{111}$ To achieve this goal, the code contained prescriptive standards for individual building components including HVAC and water heaters that were in excess of federal standards for those products. ${ }^{112}$ The court found:

The [c]ity's goals in enacting [the disputed Code] are laudable. Unfortunately, the drafters of the Code were unaware of the long-standing federal statutes governing the energy efficiency of certain HVAC and water heating products and expressly preempting state regulation of these products when the Code was drafted and, as a result, the Code, as enacted, infringes on an area preempted by federal law. ${ }^{113}$

The court was unconcerned by other provisions of the Albuquerque code that required, for example, single-family homes to have more insulation and more efficient heating, cooling and ventilating, water heating, and lighting; and that some commercial and residential structures would have to undergo thermal bypass inspections. ${ }^{114}$ These are helpful examples of the kinds of provisions that state and local governments can adopt to enhance base energy codes while avoiding federal preemption.

\section{LAND USE REGULATIONS AND ENERGY EFFICIENCY IN BUILDINGS}

\section{A. Land Use Objectives Include Energy Conservation}

There are certain aspects of building and site development not governed by the energy code that can be regulated through the

110. Air Conditioning, Heating \& Refrigeration Inst. v. City of Albuquerque, No. 08633 MV/RLP, 2008 WL 5586316, at *1 (D.N.M. Oct. 3, 2008).

111. Id. at ${ }^{*} 2$.

112. $I d$. at ${ }^{\star} 3$.

113. Id. at * 12 .

114. Id. at * 11 . 
land use system that relate directly to how much energy a building will consume and how carbon intensive it will be. Building owners, for example, can be encouraged or required to accommodate hybrid cars by providing plug in facilities in the building's parking areas. Anti-idling policies can be adopted by building managers and signs can be posted discouraging idling in parking and waiting zones immediately outside buildings. For example, San Francisco is committed to becoming America's environmental car capital. ${ }^{115}$ Among other initiatives, the city council adopted building code provisions that require new homes and office buildings to be wired for electric car chargers. ${ }^{116}$ The city also provides loans to singlefamily homeowners to encourage them to install charging stations. ${ }^{117}$ Less aggressive but similar initiatives are being undertaken in Houston, ${ }^{118}$ San Diego, ${ }^{119}$ and Portland. ${ }^{120}$

Where cities identify trails for pedestrians and bikers, site planning for new buildings can be required to connect to them, thereby reducing VMT, energy consumption, and emissions. New buildings can be required to have bike stalls on the outside or to provide indoor bike storage for workers or residents who are thereby encouraged to bike to and from work, on errands, and on outings. A new emphasis in city and regional planning has emerged concerning bicycle transportation, with some communities adopting bicycle master plans that call for street and sidewalk design standards, the location of bicycle parking facilities, incentives, and education-all to increase the use of this transportation alternative. ${ }^{121}$ Using a variety of these techniques, New York City reported a thirty-five percent increase in commuter biking between

115. See Todd Woody \& Clifford Krauss, Cities Prepare for Life With the Electric Car, N.Y. TIMES, Feb. 15, 2010, at B1, available at http://www.nytimes.com/2010/02/15/business/ 15electric.html; see also Suzanne Goldenberg, San Francisco Gears up for the Age of Electric Car, THE GuARDIAN, Feb. 17, 2010, available at http://www.guardian.co.uk/environment/ 2010/feb/17/san-francisco-electric-cars.

116. See Woody \& Krauss, supra note 115.

117. See Nick Allen, San Francisco Prepares for Electric Car Revolution, THE TELEGRAPH, Feb. 18, 2010, http://www.telegraph.co.uk/news/worldnews/northamerica/usa/ 7260958/San-Francisco-prepares-for-electric-car-revolution.html.

118. U.S. Dep't of Energy, Houston's Plug-In Vehicle Activities and Processes, ALTERNATIVE Fuels \& ADVANCED VehICLES DATA CTR., http://www.afdc.energy.gov/afdc/ vehicles/electric_deployment_case_study_houston.html (last updated June 6, 2011).

119. Josie Garthwaite, Car2go, Daimler-Backed Sharing Program, to Go Electric in San Diego, N.Y. TIMES BLOGS (July 13, 2011, 2:49 PM), http://wheels.blogs.nytimes.com/ 2011/07/13/car2go-daimler-backed-sharing-program-to-go-electric-in-san-diego/.

120. See generally City of PORTLAND, ElEctric Vehicles: The PoRTLAND Way (2010), available at $\mathrm{http} / / \mathrm{www}$.portlandonline.com/shared/cfm/image.cfm? id=309915.

121. Peter lagerwey, The Nat’l Ctr. for Bicycling \& Walking, Creating a RoadMap for Producing \& IMPLementing a Bicycle Master Plan 3 (2009), available at http://www.bikewalk.org/pdfs/BMP_RoadMap.pdf. 
2007 and $2008 .{ }^{122}$ According to the 1990 Census, only $1.2 \%$ of Portland commuters reported biking to work. ${ }^{123}$ After investing $\$ 3.50$ per resident in bicycling infrastructure and programs, "[six] percent of commuters chose to bicycle to work; and as many as [twelve] percent did so in the downtown area" in 2007.124 "In Minneapolis, [Minnesota], [twenty] percent of all trips are taken by bicycling or walking ...."125

Site plan regulations can dictate building orientation or require tree planting that can reduce energy consumption. In addition, active solar and wind generation facilities can be frustrated or facilitated by local land use law. Additional techniques within the ambit of land use regulation include space cooling systems that dissipate heat into natural heat "sinks" such as geothermal piping systems. Other conservation techniques can be facilitated as well including district energy systems and evaporative cooling and nighttime radiative cooling systems. Depending on the structure of land use law in any given state, it may be possible for local governmentsunder their delegated land use regulatory authority-to require or encourage these energy-conserving features of land development as part of their land use regulatory system.

State legislatures delegate land use authority to local governments as part of their police power, that is, their legal authority to legislate to protect the health, safety, and welfare of the people. Zoning enabling acts adopted by state legislatures routinely state that local land use regulations may be adopted to achieve the "appropriate use of the land." ${ }^{26}$ Local land use regulations that govern land development to reduce energy use and mitigate climate change are consistent with these key precepts of the enabling acts. Quite often, enabling acts state that they are to be broadly construed and, increasingly, courts interpret them expansively if the

122. Press Release, N.Y. Dep't of Transp., DOT Announces 35\% Increase In Commuter Cycling From 2007 to 2008 and Calls on Cyclists to Use Lights to be Seen and Safe (Oct. 30, 2008), available at http://www.nyc.gov/html/dot//html/pr2008/pr08_047.shtml.

123. ThOMAS GOTSCHI \& KEVIN MILls, RAILS-To-TraILS ConsERVANCY, ACTIVE TRANSPORTATION FOR AMERICA 17 (2008), available at http:/www.railstotrails.org/ resources/documents/whatwedo/atfa/ATFA_20081020.pdf (citing CITY OF PORTLAND OFFICE OF THE AUDITOR, SERVICE EFFORTS \& ACCOMPLISHMENT REPORT 2006-7 (2007)).

124. Id.

125. Id. (citing FED. HighWAY AdMIN., INTERIM REPORT TO THE U.S. CONGRESS ON THE NONMOTORIZED TRANSPORTATION PILOT PROGRAM (2007)).

126. See, e.g., John R. Nolon, Historical Overview of the American Land Use System: A Diagnostic Approach to Evaluating Governmental Land Use Control, 23 PACE ENVTL. L. REV. 821, 844 n.77 (2006) [hereinafter Nolon, Overview of Land Use System] ("In Rodgers v. Village of Tarrytown, 96 N.E.2d 731 (1951), municipalities in New York learned that they have the authority to create novel zoning devices such as the floating zone to achieve the most appropriate use of the land."); See also N.Y. TOWN LAW § 263 (McKinney 2011); N.Y. VILLAGE LAW § 7-704 (McKinney 2011). 
challenged law is clearly designed to protect the public interest. ${ }^{127}$ Challenges brought against local land use laws that are designed to conserve energy and mitigate climate change might be based on ultra vires claims (that the law exceeds the authority of the locality) or on the claim that the matter is preempted by federal or state law. Given our heighted awareness of the need to conserve energy and reduce carbon emissions, it is now clear that local regulations that do so achieve multiple public interests and advance the health, safety, and welfare of the people.

\section{B. Passive Solar, Building Form, and Orientation}

Developers of new or substantially renovated buildings must present an application to the local government in which their property is located and seek approval to build what they propose. ${ }^{128}$ This requires an administrative review by the Zoning Enforcement Officer of the community who determines, in the first instance, whether the zoning ordinance allows the use and construction details proposed and whether subdivision, site plan, or special permit approval is required or whether a variance from the zoning provisions is necessary. ${ }^{129}$ During the early stages of this review process, construction drawings have not been completed. Developers, architects, and engineers have not done detailed design work and, most certainly, lighting, electrical, and interior design professionals have not done much work, if they have even been engaged.

This early stage in the land use review process is an ideal time to require or encourage the developer to think through the most cost effective methods of reducing energy consumption and carbon emissions. It is at this stage that decisions can be made about building orientation, form, self-shading, window size and location, rooflines and extensions, height-to-floor ratios, and building features that relate to passive ventilation and cooling. ${ }^{130}$ Land use laws can require buildings to be placed appropriately on the site, for multiple buildings to be clustered, and for designs to be

127. See Nolon, Overview of the Land Use System, supra note 126, at 848.

128. JOHN R. NOLON, WELL GROUNDED: USING LOCAL LAND USE AUTHORITY TO ACHIEVE SMART GROWTH 21 (2001).

129. See id.

130. See INT'L CODE CounCiL, INT'L ENERGY CONSERVATION CODE, tbl.506.5.1(1)

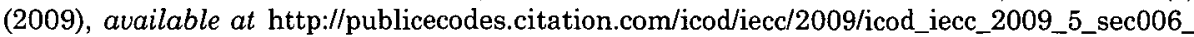
par007.htm. Even though this table is from an older version of the IECC, the table serves to illustrate the elements that can be manipulated at this early stage to achieve energy conservation. 
changed to conserve energy. ${ }^{131}$ Zoning can allow for a mix of uses, which can, in turn, enable developers to adopt more efficient district heating and cooling systems that greatly reduce energy consumption. ${ }^{132}$ It is at this stage that on-site energy generation systems in larger projects can be considered. The significant loss of energy in transmission lines from remote plants is prevented by placing generation systems on site.

\section{Building Commissioning}

It is also at this early stage in the development review process that local land use officials can discuss the possible commissioning of the building with the developer and the design team. Local land use and building standards usually do not govern the actual quality of construction, and the tightness and functional integrity of a building have a great deal to do with energy conservation. In a preapplication workshop, the developer can be encouraged to draw up and follow a building commissioning process that creates ground rules for the design and construction of the building that go beyond the traditional reach of the land use approval process. Commissioning can include higher quality and frequency functional testing of energy consuming systems and components, and even an occupancy plan where the owner states how the post-occupancy management of the building will ensure energy conservation. ${ }^{133}$

\section{Systems Approaches to Building Design}

Integral to the success of this early building proposal review process is the ability of the developer and the design team to work with local officials to review the proposed building as an entire system and to change construction elements and design standards as this system-wide review occurs. This is referred to as an "integrated design process" involving all members of the design team in an iterative approach during the stage of the approval process where normally only the building's architect is at work. ${ }^{134}$ By integrating

131. See generally Land Use Stabilization Wedge, supra note 1; John R. Nolon, Shifting Ground to Address Climate Change: The Land Use Law Solution, 10 Gov'T L. \& PoL'Y J. 23, 23-24 (2008).

132. See Linda Baker, Heating the 'Hood, AM. PLANNING Ass'N (Dec. 2009), http:// www.vancouver.ca/sustainability/documents/HeatingtheHood.pdf (discussing benefits of district heating and cooling systems).

133. See Wash. State Univ., Energy EfFiciency FaCtsheet: BuIlding CommisSIONING FOR NEW BUILDINGS (2005), available at http:/www.energy.wsu.edu/Documents/ BuildingCommissioning.pdf.

134. Whole Bldg. Design Guide Aesthetics Subcomm., Engage the Integrated Design Process, WORLD BLDG. DESIGN GUIDE, http://www.wbdg.org/design/engage_process.php (last updated Oct. 30,2010 ). 
the consideration of all design issues at the earliest stage, additional energy efficiencies of up to $35-40 \%$ can be achieved, greatly lowering the capital cost of construction and reducing postoccupancy costs of operations.

\section{E. Land Use Approval Protocols}

These approaches can be integrated into mandatory provisions of local land use laws or they can be employed as recommended protocols of the building review and approval process itself. By departmental practices, mayoral executive order, or a resolution of the city council or town board, a locality can make a commitment to energy conservation and the reduction of carbon emissions. A component of the comprehensive plan can be added by amendment outlining energy conservation goals, objectives, strategies, and implementation measures.

This clear articulation of local policy may be enough to empower the local administrative staff and planning commission to require developers of proposed projects to submit an energy conservation plan for their building that goes far beyond the standards of the energy code and moves into the building design, orientation, and commissioning initiatives discussed here.

\section{INTEGRATED NEIGHBORHOOD PLANNING}

\section{A. Densities, Sustainability, and Energy Conservation at the Neighborhood Level}

To achieve maximum energy efficiency and sustainability, planning and regulation must concentrate on scales larger than the individual building and site. In this part, we look at three strategies that focus at the neighborhood level: Transit Oriented Development, the LEED-ND rating system of the USGBC, and District Energy Systems. These constitute neighborhood planning strategies that achieve high levels of energy conservation and sus. tainability. It is at this level in appropriate neighborhoods that density must be increased, that compact and mixed uses must be provided, and that walkability must be promoted to achieve feasible transit systems, multiple sustainability objectives, and greatly reduced energy consumption. 


\section{B. Transit Oriented Development}

There has been much written about transportation choices and land use, most of it under the rubric of "transit oriented development." 135 But the terminology is varied, revealing a certain amount of ambiguity about the subject matter. Some authors write about "transit supportive" development, others use the term "transit ready" and some discuss "transportation efficient" land use patterns. ${ }^{136}$ Others appearing in the literature include "transit friendly,"137 "station area planning,"138 "transportation demand management" (TDM), "traditional neighborhood development" (TND), ${ }^{139}$ "planned unit development,"140 "development-oriented transit,"141 "transit supportive urban design," 142 "transit station communities,"143 "transit focused development,"144 and "transit villages." 145

This is a highly interdisciplinary field involving many different geographical contexts, populations, densities, and transportation modalities. Much of what is written about the subject is im. precise about how land use planning and regulation can serve the cause of cost-effective transit oriented or transportation effi-

135. Robert T. DunPhy et al., Urban Land Inst., Developing Around Transit: STRATEGIES AND SOLUTIONS THAT WORK 4 (2004). This is the most widely used term, coined by urban designer Peter Calthorpe in the 1990s. Id.

136. $I d$.

137. Transit Village Update, Transit-Friendly Dev. NewsL. (Alan M. Voorhees Transp. Ctr., New Brunswick, N.J.), May 2006, available at http://www.policy.rutgers.edu/

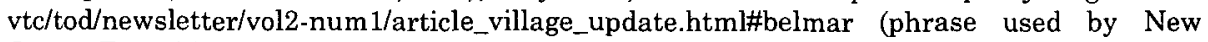
Jersey Transit).

138. Transit-Oriented Development, Real EsTate Council OF AUSTIN, InC., http:// www.recaonline.com/docs/arc/arc2006/transit_oriented.html (last visited July 5, 2012) (phrase used in Austin, TX, referring specifically to overlay zoning around transit stations).

139. Refers to the kind of development popular before post-WWII sprawl, and is essentially TOD before it got that name.

140. DUNPHY ET AL., supra note 135 , at 4 (describing a planned unit development).

141. This term actually is when transit planners are asked to accommodate existing developments, but the goal is the same.

142. Carol J. Swenson \& Frederick C. Dock, Ctr. For Transp. Studies, Univ. of Minn., REPort No. 11, URBan DEsign, Transportation, ENVIRONMENT and URBan

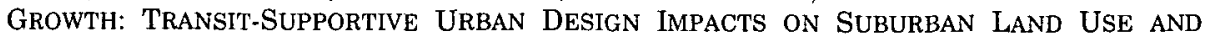
Transportation Planning (2003) (used by the Minnesota Department of Transportation).

143. Puget Sound Reg'L Council, Creating Transit Station Communities in the Central Puget Sound Region (1999) (phrase used by the Puget Sound Regional Council).

144. Douglas R. Porter, Transit-Focused Development: A Progress Report, 64 J. AM. PLAN. ASS'N. 475 (1998) (phrase used by the Transportation Research Board).

145. DUNPHY ET AL., supra note 135, at 4 ("popularized by Michael Bernick and Robert Cervero in their 1966 book, Transit Villages for the 21st Century"). The term is also used by the California and New Jersey legislatures. California Transit-Orientated Development (TOD) Searchable Database, CAL. DEP'T OF TRANSP., http://transitorienteddevelopment. dot.ca.gov/ (last visited July 5, 2012); Transit Village Initiative: Overview, STATE OF N.J. DEP'T OF TRANSP., http://www.state.nj.us/transportation/community/village/ (last updated Feb. 25, 2009). 
cient development. ${ }^{146}$ Any attempt to describe a single approach is subject to a host of exceptions in particular places, but some template for discussing the legal underpinnings of this important subject is needed. ${ }^{147}$

When density is increased for both residential and commercial uses, the distance between origin and destination is shorter and walking, bicycling, and mass transit services are more feasible. In order for increased densities to be tolerated, attractive building, landscape, and streetscape design must be employed. Studies have shown that increased population density decreases automobile ownership and the number of VMT. "[D]oubling the population density of a community could reduce per-family driving by as much as 20 to 30 percent." 148 "[O]ne study found that at high density, levels of 10,000 to 50,000 people per square mile, half of all trips were not by automobile, and walking and bicycling increased significantly." 149

Climate change mitigation requires that we create a less cardependent society. According to the Presidential Climate Action Project, "[t]he greatest potential for reducing greenhouse gas emissions and imported petroleum is to reduce vehicle miles traveledthe miles Americans drive each year." 150

TOD land use plans and zoning encourage mixed use, compact development in transit station areas, or transit neighborhoods. They locate housing and jobs near transit stops and significantly reduce the number and distance of vehicle trips. ${ }^{151}$ Encouraging land use patterns that house and employ more Americans in urban areas will cause a significant reduction in VMT while placing households in smaller, more energy efficient homes and offices, further reducing fossil fuel consumption and $\mathrm{CO}_{2}$ emissions.

\section{Transportation and Land Use Planning}

To make transit systems feasible, land use planning among localities in a transportation region must be coordinated with trans-

146. See ITE SMart Growth Task Force, InST. of Transp. EnG'RS, SMart Growth TRANSPORTATION GUIDELINES: AN ITE PROPOSED RECOMMENDEd PRACTICE 23-27, 41-72 (2003) [hereinafter SMART GROWTH TRANSPORTATION GUIDELINES] (many recommendations are proposed concerning how to improve road usage and encourage public transportation, but hardly any space is given to describe how land use regulations can affect these changes).

147. See, e.g., Alden S. Raine, Waterfront TOD, URB. LAND, May 2003, at 79; Greg Yager, Taking Transit, URB. LAND, July 2006, at 103.

148. SMART GROWTH TRANSPORTATION GUIDELINES, supra note 146, at 30.

149. Id.

150. Presidential Climate action Project, Presidential Climate Action ProJECT PLAN $\S 7: 6$ (2007), available at http://www.climateactionproject.com/docs/PCAP_12_4_ 2007.pdf.

151. Land Use Stabilization Wedge, supra note 1, at 27-28. 
portation infrastructure planning and development, which occurs at the metropolitan-area scale. Under federal law, Metropolitan Planning Organizations (MPOs) are created as consortia of state and local agencies and are charged with creating capital plans for roads, highways, and transit services in designated regions. ${ }^{152} \mathrm{Co}-$ ordination between local land use planning and MPO transportation planning is critical to the success of efforts to connect higher density urban developments and compact metropolitan developments to transit services.

Such coordination is called for under federal law, which directs MPOs to implement planning processes that "provide for consideration of projects and strategies that will ... protect and enhance the environment, promote energy conservation, improve the quality of life, and promote consistency between transportation improvements and State and local planned growth and economic development patterns." 153 Federal transportation law also requires each state to carry out a statewide transportation planning process that achieves these same objectives. ${ }^{154}$

The development of transit stations and rail and bus lines is dependent upon land use densities. ${ }^{155}$ There must be a large enough number of commuters in a relevant region to provide a base level of ridership within the area served by the transit system. In addition, ridership must be sufficiently diverse to ensure that people are traveling to work, to shop, to seek entertainment, and to go home at various times during the day, thereby increasing the cost efficiency of the transit service. Local land use plans and zoning, which regulate density and the uses to which buildings may be put, determine how much population will increase over time in a certain area, and what transportation needs new people will have. This, in turn, dictates the demand for various types of transportation services. Locally, this planning is done at the neighborhood level with an eye on the city's comprehensive plan. TOD zoning most frequently operates over an area defined by a quarter-mile radius from the transit stop. ${ }^{156}$

152. See, e.g., John R. Nolon \& Jessica A. Bacher, Climate Change, Zoning and Trans portation Planning, 36 REAL EST. L.J. 211, 220 (2007); SAN ANTONIO-BEXAR CNTY. METROPOLITAN PLANNING ORG., http://www.sametroplan.org (last visited July 5, 2012) (providing an overview of MPOs).

153. 49 U.S.C. $\$ 5303(\mathrm{~h})(1)(\mathrm{E})(2006)$.

154. 23 U.S.C. $\$ 135$.

155. For a discussion on transit-oriented development see Robert Cervero, TransitOriented Development, in LOCAL PLANNING: CONTEMPORARY PRINCIPLES AND PRACTICE 374, 374-77 (Gary Hack et al. eds., 2009).

156. Transit-Oriented Development (TOD): Overview, SUSTAINABLE CitiES INST. OF THE NAT'L LEAGUE OF CITIES, http://www.sustainablecitiesinstitute.org/view/page.basic/class/ feature.class/Lesson_TOD_Overview (last visited July 5, 2012) ("The rule of thumb is that TOD occurs within one-quarter mile, or a five to seven minute walk, of a transit station."). 
Many state enabling statutes require or encourage local governments to include a transportation element in their comprehensive plans. ${ }^{157}$ Increasingly, these transportation elements have incorporated planning strategies intended to encourage people to drive less and to walk, bicycle, and use mass transportation more frequently. Arizona's statute, for example, requires cities with more than 50,000 people to prepare a bike transportation element as part of of their comprehensive plan. ${ }^{158}$ Nevada's enabling legislation supports planning for mass transit, bicycle, and pedestrian infrastructure. ${ }^{159}$ This statute encourages local planning to include a transit element that "[s]how[s] a proposed multimodal system of transit lines, including mass transit, streetcar, motorcoach and trolley coach lines, paths for bicycles and pedestrians, satellite parking and related facilities." 160

In 2008, Florida amended its zoning enabling act that requires local comprehensive plans to consider methods of discouraging urban sprawl, supporting energy efficient development patterns, and reducing GHGs. ${ }^{161}$ The law also mandated local governments to address "transportation strategies to address reduction in greenhouse gas emissions from the transportation sector," and to consider energy conservation under its natural resources element. ${ }^{162}$

\section{Local TOD Case Studies}

The City of Yonkers, New York adopted a highly detailed master plan for its central commuter rail station area that contained certain specifications regarding the types of development the city wanted on available vacant land in the area. ${ }^{163}$ The zoning for the area was amended to provide an " 'as-of-right' status for developments that conform to the design standards contained in the [station area] master plan."164 Compliance with New York State's extensive environmental review requirements is waived for these projects, since the impacts of development contemplated by the

157. Land Use Stabilization Wedge, supra note 1, at 30.

158. ARIZ. REV. STAT. ANN. § 9-461.05(E)(9) (2011) (West).

159. NEV. REV. STAT. ANN. $§ 278.160(1)(\mathrm{r})$ (West 2011).

160. Id.

161. FLA. STAT. ANN. § 163.3177(6)(b) (West 2008). While this language was later stricken by the Community Planning Act, 2011 Fla. Sess. Law Serv. 2011-139 (West), the current version of section 163.3177 still discourages urban sprawl and promotes "walkable and connected communities" and the "conservation of water and energy." FLA. STAT. ANN. § 163.3177(6)(b) (2011).

162. Id.

163. See A Plan for Redevelopment on tHe Yonkers WATERfRONT, available at http://www.ldeo.columbia.edu/edu/plus/Westchester/A PLAN FOR REDEVELOPMENT ON THE YONKERS WATERFRONT.pdf.

164. Nolon \& Bacher, supra note 152 , at 216. 
master plan had already been studied in detail and mitigation of adverse environmental impacts provided. ${ }^{165}$

"Early in this process, a developer was selected through a request for proposals process to plan the redevelopment of two centrally-located sites, immediately adjacent to the train station. ${ }^{166}$ As the city developed its plan and conducted its environmental impact review, the private [developer] began site planning" and provided information to the city planners regarding economic and market realities. ${ }^{167}$

Information provided by citizens, environmental consultants, other professionals, and the developer were integrated as the process progressed and the master plan and designs for the two sites were adjusted.

The result is the development of Hudson Park, a [twophase] project that contains nearly 500 middle-income rental residential units, public pedestrian access to a [revitalized] waterfront, restaurants, office and retail space, and immediate access to the [renovated] train station through carefully designed walkways and entrances that provide security to riders. Hudson Park is a dramatic [TOD] where parking provided is approximately $50 \%$ less than the amount required by traditional urban zoning. This is possible because the buildings and area [appeal to] commuters who travel to work by train [and the developer's marketing was designed to attract them]. The developer saved $\$ 25,000$ in development costs for each parking space not constructed, and residents save $\$ 6,000$ annually for owning one car instead of two. Three high quality restaurants and a num. ber of retail stores catering to the middle income population[s] of these buildings have appeared [in the neighborhood]. This project and the public amenities provided by the government [to support it] are credited with sparking considerable [additional] private sector interest in the area[,]" bringing in additional riders for the transit system and reducing demand for residential development on greenfields in outlying areas. ${ }^{168}$

Zoning regulations for developments usually require standard numbers of off-street parking spaces depending on the number of dwelling units permitted or the square feet of office or retail space.

165. Id.

166. Id. at 216.

167. Id. at 217 .

168. Id. 
These standard numbers were created to apply to developments that are not transit oriented or are not compact, mixed use developments where there will be fewer cars and car trips. Reducing parking requirements, like Yonkers did in the example above, both recognizes that fewer cars will need to be accommodated in TOD developments and discourages occupants from driving.

"The suburban Bloomington, Minnesota city code provides for an " 'HX-R' " zoning district (high intensity mixed-use with residential) that is aimed at getting people out of their cars."169 Bloomington is located toward the end of a light rail system serving the metropolitan Minneapolis area. The zoning provision aims to "[r]educe vehicle trips and vehicle miles traveled ... by allowing intense development in close proximity to high frequency transit service, and by encouraging multi-purpose trips, walking trips, carpool trips and transit trips." 170 The ordinance prohibits drive-through uses that obstruct sidewalks and discourage walking. ${ }^{171}$ It provides a minimum density of thirty dwelling units per acre for residential development. ${ }^{172}$ It also provides a minimum floor area ratio of $\mathbf{1 . 5}$ and a maximum of 2.0.173 This maximum may be increased through density bonuses to encourage retail and service businesses, below grade parking, development of plazas or parks, affordable housing, public art, and sustainable design. ${ }^{174}$

Parking is restricted in the ordinance in order to "promote] walking, biking, and transit use." 175 "[P]arking must be located below grade, within structured ramps, or in individual on-street spaces parallel with and adjacent to low volume streets." ${ }^{176}$ Bicycle parking must be provided near building entrances. ${ }^{177}$ Development directly adjacent to transit stations must provide sidewalk and bikeway connections to the transit station, as well as to adjacent sites. ${ }^{178}$ The Bloomington zoning strategy evinces a commitment to development that is truly transit oriented by restricting parking, connecting to nearby transit, and locating retail and service uses within short walks of residences, thereby reducing vehicle trips and VMT.

169. Land Use Stabilization Wedge, supra note 1 , at 35.

170. City of Bloomington, MinN., Code ch. 19, $\$ 19.29(\mathrm{a})(4)$ (2011).

171. See id. $\S 19.29(\mathrm{k})$.

172. Id. $\S 19.29(\mathrm{f})(1)$.

173. Id. $\S 19.29(\mathrm{~g})(1),(4)$.

174. Id. $\S 19.29(\mathrm{~g})(4)(\mathrm{A})-(\mathrm{F})$.

175. Id. $\S 19.29(\mathrm{i})(2)$.

176. Id. $\S 19.29(\mathrm{i})(2)(\mathrm{A})$.

177. Id. $\$ 19.29(\mathrm{i})(3)$.

178. Id. $\S 19.29(\mathrm{k})(6)$. 


\section{E. Transportation Efficient Development}

Even where communities are not currently served by transit systems, they can create compact, mixed use neighborhoods that reduce car trips and miles traveled. The country cousin of TOD is Transportation Efficient Development (TED), where the emphasis is on reducing car trips within TED zoning districts. Zoning controls can limit the size of housing units and combine retail, office, and residential land uses, putting services, shops, and jobs in proximity to homes. Zoning controls may also be used to require new construction to meet energy standards and further reduce GHG emissions. Communities not yet served by transit can design one or more priority growth districts of this type and create overlay zones for them that allow greater densities and more land uses than permitted in the underlying zoning districts. By clustering development strategically, these growing localities position themselves for future service by commuter rail or bus rapid transit, thereby becoming "transit ready."

The Town of Malta, located outside of Albany, New York, adopted a TED approach to rezoning its central business district by using an overlay zone to prepare for future transit services. 179 The Malta zoning law provides for compact, mixed use development emphasizing pedestrian amenities. Malta is not currently served by transit, but the regional Capital District Transportation Plan calls for bus rapid transit service to downtown Malta in the future. In anticipation, the overlay zone states that " $t]$ o promote pedestrian activity and multimodal transportation, developments should be located within 1320 feet of an existing or future transit stop as approved by the Planning Board."180

Suburban areas that adopt higher density, mixed use zoning will find it easier politically to adopt strong environmental protection ordinances applicable to the land outside high-density zones. Where state law permits, density bonuses may be allotted in the transportation efficient overlay area, and cash contributions may be secured from developers in exchange. This money can be used to purchase development rights from landowners in valuable open space areas outside the higher density zone, areas that mitigate climate change through sequestration. 


\section{F. LEED for Neighborhood Development}

\section{Overview of the LEED-ND Rating System}

LEED-ND advances the USGB rating system by focusing on developments and their relationship to their adjacent neighborhoods. ${ }^{181}$ The Congress for the New Urbanism (CNU) and the Natural Resources Defense Council (NRDC) collaborated with the USGBC to create LEED-ND, which began its pilot phase in 2007. ${ }^{182}$ According to the USGBC, the LEED-ND rating system "encourages smart growth and New Urbanist best practices by promoting the location and design of neighborhoods that reduce vehicle miles traveled (VMT) and creating developments where jobs and services are accessible by foot or public transit." 183 It also promotes more efficient energy systems and water use, which are "especially important in urban areas [where these services are expensive or] where the infrastructure is often overtaxed."184 Though most applicable on the neighborhood scale, there are no size thresholds for projects seeking ND certification. According to the Green Building Certification Institute (GBCI) of the USGBC "[p]rojects may constitute whole neighborhoods, portions of neighborhoods, or multiple neighborhoods." ${ }^{85}$ GBCI does recommend, however, that projects not be smaller than two habitable buildings or larger than about half a square mile. ${ }^{186}$

Like the other LEED rating systems, LEED-ND is divided into categories. ${ }^{187}$ In each category, there are prerequisites that must be met and a variety of points that may be earned. 188 Developers must meet all prerequisites and earn a specified number of points for basic certification or to achieve certification at higher levels: silver, gold, or platinum. ${ }^{189}$

LEED-ND points and prerequisites are divided into five categories: Smart Location and Linkage (SLL), Neighborhood Pattern

181. See LEED for Neighborhood Development, U.S. GREEN BLDG. COUNCIL, http:// www.usgbc.org/DisplayPage.aspx?CMSPageID=148 (last visited July 5, 2012).

182. Id.

183. ND-Specific Guidance, LEED ONLINE, https://www.leedonline.com/irj/servlet/prt/ portal/prtroot/docs/guid/30a0a343-df18-2d10-5a85-fe6a8528385b (last visited July 5, 2012).

184. Id.

185. About: LEED for Neighborhood Development, GREEN BLDG. CERTIFICATION INST., http://www.gbci.org/leednd (last visited July 5, 2012).

186. U.S. GREEN BLDG. COUNCIL, LEED 2009 For NeIGHBorhood DEvelopment, at xiv (2011), available at http://www.usgbc.org/ShowFile.aspx?DocumentID=9449 [hereinafter USGBC, LEED FOR NEIGHBORHOOD DEVELOPMENT].

187. Id. at vii-viii.

188. Id.

189. Id. 
and Design (NPD), Green Infrastructure and Buildings (GIB), Innovation and Design Process (IDP), and Regional Priority Credits (RPC). ${ }^{190}$ Within the first three categories, (SLL, NPD, and GIB) prerequisites are identified that embody the principles of sustainable development.

The Smart Location and Linkage prerequisites, for example, encourage development within established communities and near public transit. ${ }^{191}$ Developments seeking LEED-ND status as new neighborhoods must protect prime farmland, wetlands, and water bodies from development, and avoid floodplains, imperiled species, and ecological communities. ${ }^{192}$

Zoning standards and local laws that foster development in existing neighborhoods or encourage the use of distressed or underutilized older buildings or brownfields will help projects seeking certification to satisfy LEED-ND smart location requirements. ${ }^{193}$ Zoning provisions that permit transfer of development rights from farmlands, or other ecologically important areas, to existing neighborhoods also further ND principles. Such provisions manage climate change by preserving the sequestering environment and by promoting more energy efficient human settlements. ${ }^{194}$

The Neighborhood Pattern and Design prerequisites of LEEDND promote livability, walkability and transportation efficiency, as well as communities that are physically well-connected with the neighborhood beyond the buildings seeking certification. ${ }^{195}$ NPD points can be earned by increasing the density permitted by zoning to accommodate a transit agency's need for riders. ${ }^{196}$ LEED-ND, for example, requires that projects have a minimum floor-arearatio of 80 for commercial buildings or a minimum of seven dwelling units per acre for residential structures. ${ }^{197}$ These standards are at the lower range of density needed to provide sufficient riders to support transit services.

A prerequisite in the Green Infrastructure and Buildings category offers an example of how LEED-ND standards exceed the provisions of base energy codes. GIB Prerequisite 2 requires "the design and construction of energy-efficient buildings that reduce air, water, and land pollution and [that mitigate] adverse environmental [impacts] from energy production and consumption." ${ }^{198}$

190. Id. at xii.

191. See id. at 1-39.

192. Id. at 10-21.

193. Id. at 26.

194. See id. at 15-18.

195. Id. at 41.76.

196. Id. at 53-54.

197. Id. at 42.

198. Id. at 78 . 
This requirement forces developers to engage designers and consultants who understand how to minimize environmental impacts, including $\mathrm{CO}_{2}$ emissions. LEED-ND encourages developers to exceed the standards imposed by most local energy code regulations. For example, any newly constructed buildings that are four stories or higher must be ten percent more energy efficient than required by ASHRAE 90.1-2007, which is the base energy code requirement for commercial buildings in many states. ${ }^{199}$ In addition, buildings undergoing major renovations must be five percent more efficient than this standard. ${ }^{200}$ Within a LEED-ND project, ninety percent of all new residential buildings that are three stories or less must meet Energy Star criteria or the equivalent; this too exceeds local energy code standards. ${ }^{201}$

Beyond prerequisites, the credits that may be earned under LEED-ND provide numerous options for developers to make their ND projects sustainable. At the site level, for example, they can choose to design for habitat and wetland conservation or to restore damaged natural resources and earn points for doing so. ${ }^{202}$ Regarding VMT, they can adopt transportation demand management for the occupants of their buildings ${ }^{203}$ or reduce the footprint of their parking surfaces and buildings. ${ }^{204}$ Regarding water efficiency, they can elect to use low-flow plumbing fixtures or to adopt wastewater management protocols. ${ }^{205}$ They can earn points by electing to orient buildings for maximum solar exposure, ${ }^{206}$ to reduce light pollution, ${ }^{207}$ or to install district heating and cooling facilities. ${ }^{208}$

\section{Municipal Use of LEED-ND to Guide Land Development}

The LEED-ND prerequisites and elective credits serve as an impressive menu of options to achieve sustainability. In the neighborhood context, there are many opportunities for coordinating private sector and public planning, short of adopting LEED-ND standards as mandatory regulations. In some settings, it may be difficult for developers to achieve ND certification without such coordination. Unless they are building a large new neighborhood, for example, it is hard for developers to meet prerequisites such as

199. Id.

200. Id

201. Id. at 79

202. Id. at 36-37.

203. Id. at 65-66.

204. Id. at 60-61.

205. Id. at 86-87.

206. Id. at 96-97.

207. Id. at 104-06.

208. Id. at 99 . 
"walkable streets" 209 or a "connected and open community" 210 without compatible local planning and zoning. Points may be earned under LEED-ND for reduced parking footprints, but projects must meet the parking requirements of the zoning code, which might make it impossible to earn those parking credits. Points available for stormwater management are easier to earn if the building fits into a local floodplain management plan and stormwater system. Local capital budgets can help developers earn points for a variety of sustainable features, such as access to recreational facilities, transit stops, and street and bicycle networks.

Where the local government wants to help particular developers earn points or, more ambitiously, to encourage all developers to contribute to more sustainable neighborhoods, LEED-ND standards provide strategic guidance for the reform of local land use law. The principles followed by the USGBC, CNU, and the NRDC in creating LEED-ND apply equally well to the creation of local land use regulations as they do to guiding developers in seeking certification.

Local governments may use ND standards as a checklist to evaluate their comprehensive plans, zoning and other land use regulations, capital budgets, and other activities to determine whether and to what extent they achieve neighborhood sustainability and how they can be improved without imposing undue costs on the development community. To the extent that local governments do this, they make it easier for developers to win ND certification and they promote the development of sustainable neighborhoods at the same time. Points can be earned for projects located in neighborhoods with proper street networks, for example, and for those that provide for district heating systems. Engineering streets to ensure greater connectivity, minimizing building uses that require vehicle drive-through activity on sidewalks (banks and fast food establishments), providing more pedestrian use and amenities, building paths for bikes and scooters, and planning energy systems at the district level are more easily accomplished if fostered by local comprehensive planning, capital spending, and land use regulations.

Zoning can allow for district heating and cooling plants, as well as solar and wind systems, to be installed in certain buildings or their sites; land use review protocols can be used to encourage owners to provide them, and density bonuses can be granted to provide a financial incentive. Green Infrastructure and Buildings credit 11 "encourage[s] on-site renewable energy production to re- 
duce the adverse environmental and economic effects associated with fossil fuel energy production and use."211 Solar, wind, geothermal, small-scale/micro hydroelectric, and biomass facilities that reduce a project's annual energy costs by five percent or more earn points in the GIB category. ${ }^{212}$ Greater energy cost savings earn additional points. ${ }^{213}$ San Francisco made renewable energy more feasible by amending its zoning regulations to add a special permit system for mounting wind towers to individual buildings in a certain district. ${ }^{214}$ With that simple land use change, all developers in the designated zone were then able to provide wind turbines and earn these GIB credits under the LEED-ND system.

One of the historic inefficiencies in our zoning system is the lack of respected standard-setting agencies to guide the drafting of local regulations. Some states have provided, from time to time, technical assistance to localities regarding these matters. In most cases, however, localities are not guided by carefully considered standards. This is due, in part, to the fact that local circumstances differ, and consequently, mandatory standards worked out at the state or federal level may be inappropriate. Since the advent of zoning in the 1920 s, there has been a constant need for guidance as localities regulate and make choices to fit their local needs. This need is exacerbated by the complex demands of sustainable development and climate change mitigation. To a degree, the LEEDND system responds to this need by providing intelligent practices that can be used to guide sustainable neighborhood planning and regulation.

\section{G. District Energy Systems}

Buildings can be made up to eighty percent more energy efficient through distributed-generation systems, which capture waste heat and use it for water and space heating and cooling. ${ }^{215}$ Such systems operate at a scale larger than the individual building, optimally among a large number of buildings in close proximity to one another where maximum efficiency is possible. Energy ef-

211. Id. at 98 .

212. Id.

213. Id.

214. San Francisco, CaL., Mun. Planning Code $\S 933$ (2011).

215. Shankar Karki \& Michael D. Mann, Efficiency Improvements through Combined Heat and Power for On-Site Distributed Generation Technologies, 22 COGENERATION \& DISTRIBUTED GENERATION J. 19, 21 (2007), available at http://www.localpower.org/ documents/reporto_sk_efficiencydg.pdf; How Gas Turbine Power Plants Work, U.S. DEP'T OF ENERGY, http://www.fossil.energy.gov/programs/powersystems/turbines/turbines_ howitworks.html (last updated Jan. 26, 2011); Cogeneration/Combined Heat and Power, CTR. FOR CLIMATE \& ENERGY SOLUTIONS, http://www.pewclimate.org/technology/factsheet/ CogenerationCHP (last visited July 5, 2012). 
ficiencies of this sort should be a part of the neighborhood planning process and integrated into local efforts that encourage sustainability through compact, mixed/use development. Energy efficient neighborhoods can be planned that encourage green building development, on-site generation, the use of renewable sources of power, efficient distribution systems, and combined heat and power systems shared by multiple buildings. LEED-ND awards a credit for "District Heating and Cooling," which a developer can earn by designing a system to meet eighty percent of a project's heating or cooling consumption or both through district heating and cooling. ${ }^{216}$

In higher density, mixed use neighborhoods there is great potential for energy efficiency through the creation of a District Energy System (DES). A DES produces energy in the form of steam, hot water, or chilled water, which is transported through an underground closed-loop piping system to buildings connected to the district's network. ${ }^{217}$ A DES can mitigate climate change even further by deriving its energy from renewable fuels such as biomass, municipal waste, and lower carbon alternatives such as natural gas or, in some areas, wind turbines or solar arrays. ${ }^{218}$

To operate most efficiently, districts should contain buildings with different energy needs, such as multi-family buildings, offices, municipal buildings, warehouses, hospitals, nursing homes, mills, and factories. When they are located in reasonable proximity, the energy loads of each can complement one another (because their energy needs are varied at different times of day) and the costs of heating and cooling can be reduced. In those buildings, heat exchangers can draw the energy needed to meet their space and water heating needs, returning the water to the plant for recirculation within a closed loop system. ${ }^{219}$ This eliminates the need to install individual boilers in each building, which reduces capital costs. $^{220}$ In older areas where existing furnaces, chillers, water heaters, and other cooling and water facilities are obsolete, the DES approach can cost-effectively address the need for system modernization. There are inherent fuel efficiencies in this system.

A dramatic example of this technology that transcends the neighborhood scale is occurring in Sydney, Australia. The cornerstone of Sydney's new system is trigeneration that employs gas

216. USGBC, LEED FOR NEIGHBORHOOD DEVELOPMENT, supra note 186 , at 99.

217. Baker, supra note 132; see also R. NEAL ElliotT \& MARK SPURR, CoMBINEd HEAT AND POWER: CAPTURING WASTED ENERGY, at V (May 1999).

218. See Baker, supra note 132.

219. See ELLIOTT \& SPURR, supra note 217, at 25.

220. Id.; see also Baker, supra note 132. 
burning engines for electricity generation. ${ }^{221}$ The engines burn either natural gas or renewable gas, thereby reducing or eliminating the amount of GHG emissions associated with providing electricity to the city. ${ }^{222}$ Through its "Trigeneration Master Plan," the city hopes to meet seventy percent of its energy needs by combining this electrical generation with distributed heating and cooling. ${ }^{223}$ Currently eighty percent of Sydney's energy is provided by coal-fired plants, where two-thirds of the energy is lost as heat or in transmission. ${ }^{224}$ By reducing Sydney's dependence on coal, trigeneration will reduce Sydney's GHG emissions between 1.1 to 1.7 million metric tons a year. ${ }^{225}$ The goal of seventy percent energy through trigeneration is paired with the estimates that the city could bridge the remaining thirty percent through a small amount of grid electricity, renewable sources, and energy efficiency measures. ${ }^{226}$ The capital cost of developing this plan would total $\$ 950$ million and projected annual energy savings are $\$ 200$ million. . $27^{2}$

To increase the use of district energy systems, the local land use regulatory system will need to adjust to allow, or even to incentivize, them. ${ }^{228}$ They must be allowable uses and practices under local zoning and site plan regulations, as well as local building and energy codes. They may be encouraged through bonus zoning provisions that waive zoning requirements or provide additional development densities for developers who adopt DES technologies.

The City of Burlington, Vermont revised its comprehensive plan to include a commitment to transitioning to renewable sources of energy as well as to cogeneration and district heating, including biomass-fueled district heating technologies. ${ }^{229}$ Subsequent to that revision, Burlington residents voted in favor of a smart-grid bond to provide $\$ 13.5$ million in upgrades, including net

221. Kinesis Consortium, City of Sydney Decentralised Energy Master Plan Trigeneration, CITY OF SYDNEY 22 (2010), http://www.cityofsydney.nsw.gov.au/Council OnExhibition/documents/CityofSydney-DEMPTrigeneration-Report20101129-LowRes.pdf [hereinafter Sydney's Master Plan].

222. Id.

223. Powering Sydney, CITY OF SYDNEY, http://www.cityofsydney.nsw.gov.au/2030/ makingithappen/AllanJones.asp (last visited July 5, 2012) [hereinafter Powering Sydney].

224. $I d$.

225. $I d$.

226. See id.; Sydney's Master Plan, supra note 221, at 4.

227. Sydney's Master Plan, supra note 221, at 32.

228. See John R. Nolon, Climate Change and Sustainable Development: The Quest for Green Communities-Part II, 61 PLANNING \& ENVTL. L. 3, 3-12 (2009).

229. See Annalisa Parent, South Burlington Comprehensive Plan Nearly Complete, THE OTHER PAPER (Mar. 31, 2011), http://www.otherpapersbvt.com/south-burlingtoncomprehensive-plan-nearly-complete.html. 
metering. ${ }^{230}$ Planners in Washington, D.C. have recognized that the absence of permissive language pertaining to DES in its local zoning law discourages the use of district energy systems. ${ }^{231}$ They recommend amending the zoning to expressly permit the use of district energy systems in all zoning districts. ${ }^{232}$

Another example can be found in St. Paul, Minnesota. The cogeneration system used in this city is the result of a partnership between Ever-Green Energy and Duke Energy Generation Services. ${ }^{233}$ In 2003, Duke Energy opened a wood-fired combined heat and power facility in downtown St. Paul. ${ }^{234}$ Before the plant was built, Duke Energy agreed to a twenty-year power agreement with Ever-Green, thereby ensuring a market for the plant's output. ${ }^{235}$ The wood is burned to heat water, which then creates steam. ${ }^{236}$ This steam then turns a turbine, which creates electricity. ${ }^{237}$ Instead of letting the steam evaporate, the steam is then used to heat out-flowing water, thereby providing hot water to the connected buildings. ${ }^{238}$ In addition, the wood burned is "clean wood waste generated in the Twin Cities metro area," 239 which "reduce[s] greenhouse gas emissions by more than 280,000 tons per year." ${ }^{40}$ This single plant is capable of producing " 25 megawatts of electricity and 65 megawatts of thermal energy." ${ }^{411}$ The thermal energy reaches over 31 million square feet of St. Paul building space. ${ }^{242}$ This system replaces about sixty percent of the district's use of coal and oil by providing heat and cooling to the majority of the buildings in the downtown St. Paul neighborhood. ${ }^{243}$

One of the most compelling examples of CHP is found on the campus of the University of Texas at Austin. The UT-Austin CHP system provides " $100 \%$ [of the] power, heating and cooling re-

230. Joel Banner Baird, Burlington Approves Smart Grid in Citywide Vote, BurLINGTON FreE PREss (June 28, 2011, 8:24 PM), http://www.burlingtonfreepress.com/ article/20110628/NEWS02/110628031/Burlington-approves-smart-grid-citywide-vote.

231. CLLARION ASSOCS. \& FARR ASSOCS., SUSTAINABILITY DIAGNOSIS FOR THE WASHINGTON, D.C. ZONING REviEw 14-15 (2008), available at https://www. communicationsmgr.com/projects/1355/docs/Diagnosis Draft 17.pdf. 232. See id. at 15.

233. St. Paul Cogeneration, Ever-Green ENERGy, http://www.ever-greenenergy.com/ clients/cogeneration.html (last visited July 5, 2012) [hereinafter St. Paul Cogeneration].

234. Id.

235. $I d$.

236. $I d$.

237. $I d$.

238. Id.

239. Id

240. Press Release, Trigen-Cinergy Solutions, Combined Heat and Power Plant Begins

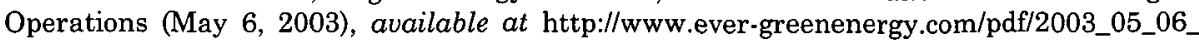
CHPStartup.pdf.

241. St. Paul Cogeneration, supra note 233.

242. Id.

243. Id. 
quirements for 16 million [square feet] and 150+ buildings."244 The CHP system has a capacity of 137 megawatts, ${ }^{245}$ and is capable of operating at ninety percent efficiency. ${ }^{246}$ In addition, the system has 46,000 tons of chilled water capacity. ${ }^{247}$ This system has produced heat and power with $99.9998 \%$ reliability over the last thirty-five years. ${ }^{248}$

\section{CONCLUSION: ENERGY CONSERVATION DISTRICTS}

Planning to promote District Energy Systems is a nascent notion that is only beginning to influence local land use decisionmakers. So too is the insinuation of the standards contained in the LEED-ND rating system into local plans and regulations. While TOD is a more familiar technique, it is rapidly evolving to incorporate design standards, amenities, and objectives that embrace a variety of sustainability objectives. These innovative neighborhood planning techniques can be integrated into a single program that, in turn, can organize and guide federal and state energy conservation and climate change policies.

At first blush these three strategies may seem incompatible. Each one involves a different type of neighborhood with various shapes and features. District Energy Systems organize around a cluster of diverse types of buildings with varying energy needs; TOD focuses on a transit station and a tight radius of land around it. LEED-ND encompasses district energy and transit orientation in its certification system and provides a broad strategic framework for local governments to follow in improving their land use plans and regulations to achieve sustainable development. ${ }^{249}$

Federal and state policies and programs should encourage localities with the potential for creating district energy systems and transit oriented neighborhoods to rezone them as Energy Conservation Zoning Districts calibrated to achieve multiple objectives of sustainable development. In the orchard of energy conservation and climate change mitigation techniques, this strategy may be the lowest hanging fruit. Over seventy percent of electricity pro-

244. Juan Ontiveros, Exec. Dir. Util. \& Energy Mgmt., Presentation Regarding the University of Texas-Austin's CHP and District Energy System (Nov. 2010) (presentation available at $\mathrm{http}: / / \mathrm{ww}$.epa.gov/chp/documents/meeting_110110_Ontiveros.pdf).

245. Id.

246. Id.

247. Id.

248. $I d$.

249. The Land Use Law Center has published a guidebook on this subject through the United States Green Building Council. Land Use Law Ctr., Pace Univ. Sch. of Law, Technical Guidance Manual for Sustainable Neighborhoods: How to Use the LEED for Neighborhood Development Rating System to Audit Local Plans, Codes, and Policies (2011) (unpublished manuscript) (on file with author). 
duced in the United States is consumed by buildings, which also account for over forty percent of total domestic energy consumption; the construction of buildings is regulated at the local level through energy codes and land use standards. As much as eighty percent of the energy used to produce electricity is wasted at the point of generation or in line transmission, waste largely eliminated by on-site generation in district energy systems, which land use regulation can facilitate. Energy use in buildings correlates with climate change; over thirty-five percent of $\mathrm{CO} 2 \mathrm{e}$ emissions, nearly 2.5 gigatons, are attributable to energy consumed in buildings. Transportation accounts for a third of domestic GHG emissions and well over half of that is traceable to personal vehicles that are used to traverse the sprawling settlement pattern that is the result of prevailing land use policies. Per capita energy consumption and GHG emissions are over double in low density developments when compared to the higher density neighborhoods that Energy Conservation Zoning Districts create. ${ }^{250}$

Local officials must learn how to determine what types of buildings and energy uses should be incorporated into such a zoning district and how to change land use regulations to facilitate district energy systems, more energy efficient construction, renewable energy facilities, transit-oriented development, and other sustainability techniques. Localities need assistance in providing incentives to cover the capital costs of green buildings and district-wide systems. State and federal support for this Energy Conservation Zoning District initiative can unlock the potential these strategies have for energy conservation and climate change mitigation.

One model for such a program is the federal Enterprise Zone initiative and the New York Empire Zone program. In 1988, the Federal government passed the Enterprise Zone Development statute ${ }^{251}$ and enhanced it with more effective benefits in 1993..$^{252}$ The criteria for identifying qualifying zones were contained in the 1988 legislation. ${ }^{253}$ In selecting enterprise zones, the objectives were poverty reduction and urban job development and so the standards for qualifying zones were the area's unemployment rate, ${ }^{254}$ poverty rate, ${ }^{255}$ and the median income, ${ }^{256}$ among other factors.

250. See supra notes 32-34 and accompanying text

251. Housing and Community Development Act of 1987, Pub. L. No. 100-242, § 701, 101 Stat. 1957 (1988).

252. Omnibus Budget Reconciliation Act of 1993, Pub. L. No. 103-66, § 13301(a), 107 Stat. 543 (1993).

253. Housing and Community Development Act $\S 701$.

254. 42 U.S.C. $\S 11501(\mathrm{c})(3)(\mathrm{C})(2006)$.

255. Id. $\$ 11501(\mathrm{c})(3)(\mathrm{D})$.

256. Id. § 11501 (c)(3)(E). 
A similar program was adopted two years earlier in New York, known as the New York State Economic Development Zones, or Empire Zone program. ${ }^{257}$ To designate qualifying Empire Zones eligible for state financial and technical assistance and tax incentives, the State Commissioner of Economic Development looked at the area's poverty rate, ${ }^{258}$ unemployment rate, ${ }^{259}$ and rate of public assistance. ${ }^{260}$ Both the Enterprise Zone program and the Empire Zone program used census-based metrics to identify eligible areas within which local governments and employers adding new jobs could receive government benefits. A similar approach could be taken to identify Energy Conservation Zoning Districts (EZ Districts) in which local governments, developers, and building owners could qualify for a range of benefits if they further the strategies for energy conservation, climate change mitigation, and sustainability discussed in this article.

There are a number of available indices that could be considered to determine where maximum energy conservation can be achieved and which neighborhoods should qualify under the EZ District program. Released in March 2011, the American Housing Survey for the United States: 2009 contains a wide range of information, including residential square footage per person, lot size, and rooms per person. ${ }^{261}$ The U.S. Energy Information Administration ("the EIA") reports electricity consumption statistics for various types of residential and commercial buildings on a per household and per employee basis. ${ }^{262}$ These EIA reports are instructive. Single-family homes, for example, use 108.4 million Btu per household per year, 2-4 unit apartment buildings use 85.0 million Btu per household per year, while apartment buildings with five or more units consume 54.4 million Btu per household per year. ${ }^{263}$ This type of data can be used to target neighborhoods and development patterns where energy efficiency can result. Federally-established Metropolitan Planning Organizations and state departments of transportation conduct regional transit planning

257. N.Y. GEN. MUN. LAW $\S \S 955-69$ (McKinney 2011).

258. Id. $\S 958(\mathrm{a})(\mathrm{i})(\mathrm{A})$.

259. Id. $\S 958(\mathrm{a})(\mathrm{i})(\mathrm{B})$.

260. Id. § 958(d)(iii).

261. U.S. CEnsus Bureau, AMERICAN Housing SuRvey for the United STATES: 2009 (2009), available at http://www.census.gov/prod/2011pubs/h150-09.pdf.

262. 2005 RECS Survey Data, U.S. ENERGY INFO. ADMIN., http://www.eia.gov/ consumption/residential/data/2005/index.cfm\#summary (last visited July 5, 2012); 2003 Commercial Buildings Energy Consumption Survey: Consumption and Expenditures Tables, U.S. ENERGY INFO. ADMIN., http://www.eia.gov/emeu/cbecs/cbecs2003/detailed_tables_2003/ detailed_tables_2003.html (last visited July 5, 2012).

263. U.S. Energy Info. AdMin., TABLE US1: TOTAL ENERGY CONSUMPTION, EXPENDITURES, AND INTENSITIES, 2005, at 2 (2009), available at http://www.eia.gov/ consumption/residential/data/2005/c\&e/summary/pdf/tableus1part1.pdf. 
and can identify qualifying transit station areas where significant new ridership will further transit development. State tax departments maintain codes for land and building use and can identify tax districts with clusters of building types that are needed in an EZ District.

The federal EZ District program could provide planning grants for local governments, mapping services, statistical data packages, best practices, infrastructure subsidies, technical assistance grants, and tax credits to property owners and developers. This federal initiative could be dependent on the participation of the state government in the EZ Program, patterning itself after the cooperative federalist approach of the Coastal Zone Management Act. ${ }^{264}$ States could be told that federal benefits depend on states matching the grant and tax credit allocations and upon programs for helping local governments with best practices, technical assistance, and neighborhood selection. Local governments with qualifying neighborhoods that agree to adopt the EZ District program including enhanced energy code adoption, effective code enforcement, TOD, District Energy System facilities, and neighborhood sustainability standards, would be eligible to participate. With state and federal support, localities willing to adopt an EZ District program could apply for planning grants, secure assistance in adopting best practices, qualify for infrastructure subsidies and, in turn, make property owners and developers in EZ Program neighborhoods available for tax credits.

The EZ District program has the potential to succeed because it lines up with and furthers policy objectives that are bipartisan and ascendant. It lowers the cost of living for middle- and moderate-income Americans, reduces the nation's dependence on energy imports, furthers the development of renewable energy facilities, rests on the initiative of local governments that voluntarily choose to participate, and is flexible enough to fit local circumstances in the fifty states. It is a devolved and democratic approach. Coincidentally, it mitigates climate change and captures the support of those who understand the clear threat it poses to our economy and environment. 